2018-01

Sea ice, ice-rafting, and ocean climate across Denmark Strait during rapid deglaciation (similar to 16-12 cal ka BP) of the Iceland and East Greenland shelves

\title{
Andrews, JT
}

http://hdl.handle.net/10026.1/10748

10.1002/jqs.3007

Journal of Quaternary Science

Wiley

All content in PEARL is protected by copyright law. Author manuscripts are made available in accordance with publisher policies. Please cite only the published version using the details provided on the item record or document. In the absence of an open licence (e.g. Creative Commons), permissions for further reuse of content should be sought from the publisher or author. 


\section{Journal of Quaternary Science}

\section{Sea ice, ice-rafting, and ocean climate across Denmark Strait during rapid deglaciation ( 16 to $12 \mathrm{cal} k \mathrm{ka}$ B) of the Iceland and East Greenland shelves}

\begin{tabular}{|r|l|}
\hline Journal: & Journal of Quaternary Science \\
\hline Manuscript ID & JQS-17-0023.R2 \\
\hline Wiley - Manuscript type: & Research Article \\
\hline Date Submitted by the Author: & 13 -Oct-2017 \\
\hline Komplete List of Authors: & $\begin{array}{l}\text { Andrews, John; University of Colorado, Arctic and Alpine Research; } \\
\text { Cabedo Sanz, Patricia; University of Plymouth, Earth and Environmental } \\
\text { Sciences } \\
\text { Belt, Simon; University of Plymouth, Petroleum and Environmental } \\
\text { Geochemistry Group } \\
\text { Jennings, Anne; University of Colorado, INSTAAR } \\
\text { Olafsdottir, Saedis; University of Bergen, Department of Earth Science and } \\
\text { Bjerknes Centre for Climate Research } \\
\text { Geirsdóttir, Áslaug; University of Iceland, Institute of Earth Sciences and } \\
\text { Department of Earth Sciences }\end{array}$ \\
\hline Keywords: & $\begin{array}{l}\text { Denmark Strait, Deglaciation, Ocean reservoir correction, IP25 biomarker, } \\
\text { Sedimentology }\end{array}$ \\
\hline
\end{tabular}


1 Sea ice, ice-rafting, and ocean climate across Denmark Strait during rapid

2 deglaciation ( $\sim 16$ to 12 cal ka BP) of the Iceland and East Greenland shelves

4 Andrews, J.T. ${ }^{1}$, Cabedo-Sanz, P. ${ }^{2}$, Jennings, A.E. ${ }^{1}$, Ólafsdóttir, S ${ }^{3}$, Belt, S.T ${ }^{2}$, 5 Geirsdóttir, Á.

6

1. INSTAAR and Department of Geological Sciences, University of Colorado, Boulder, 8 CO 80309, USA

2. School of Geography, Earth and Environmental Sciences, University of Plymouth,

11 Drake Circus, Plymouth, PL4 8AA, UK

3. Department of Earth Science and Bjerknes Centre for Climate Research, University of 15 Bergen, Norway

16

4. Department of Earth Sciences, University of Iceland, IS-101, Reykjavík, Iceland

JTA: ORCHID 0000-0003-3169-5979

andrewsi@colorado.edu 


\section{Abstract}

29 A suite of cores from the Northwest Iceland and East Greenland shelves sampled

30 fossiliferous or unfossiliferous basal glacial diamictons. Radiocarbon dates above the

31 diamictons are similar on both shelves, however, the value of the ocean reservoir

32 correction, $\Delta \mathrm{R}$, is unknown. Deglaciation occurred either $\sim 16$ or 14 cal ka BP depending

33 on the choice of $\Delta \mathrm{R}$. The ice sheets were behind the present coastline by $12.2 \mathrm{cal} \mathrm{ka}$ BP.

34 We examine seven cores that record the glacial/deglacial transition and present new data

35 on the sea-ice biomarkers $\mathrm{IP}_{25}$ and $\mathrm{C}_{25: 2}$ from four of the cores plus data on IRD counts,

36 grain-size spectra, $\delta{ }^{18} \mathrm{O}$ on the near-surface planktonic foraminifera Neogloboquadrina

37 pachyderma (s), foraminifera assemblages, and quartz $\% . \quad \mathrm{IP}_{25}$ concentrations are

38 markedly higher for the East Greenland sites, while they are frequently below the limit of

39 quantification off Iceland; observations that parallel the wt $\%$ quartz in the sediments.

40 The $\delta^{18} \mathrm{O}$ N. pachyderma (s) data show a strong gradient across Denmark Strait with

41 lighter $\delta^{18} \mathrm{O}$ values towards the East Greenland shelf indicative of a large freshwater flux.

42 The presence of the chilled Atlantic Water benthic foraminifera, Cassidulina neoteretis,

43 indicates that rapid ice sheet retreat was associated with ocean forcing, combined with

44 other factors.

45 Keywords: Denmark Strait, Deglaciation, Ocean reservoir correction, IP25 biomarker,

46 Sedimentology

47 Abstract: 254 words

48 Main text: 6455 words 


\section{Introduction}

50 A significant number of cores from around Iceland and E Greenland penetrate a basal

51 diamicton, often containing shells and foraminifera, overlain by glacial marine sediments

52 rich in ice rafted debris (IRD) (Jennings et al., 2000; Olafsdottir, 2004). At the Late

53 Glacial Maximum (LGM), reconstructions and marine core data (Andrews, 2008;

54 Andrews et al., 1998, 2000; Dunhill, 2005; Funder et al., 2004; Hubbard et al., 2006;

55 Vasskog et al., 2015) indicate that the Iceland and Greenland ice sheets were terminating

56 at their shelf breaks with deposition on the slopes above the Denmark Strait. In a

57 companion paper (Andrews et al., 2017a) we documented the variations of the Iceland

58 and Greenland ice sheets during Marine Isotope Stage (MIS) 3 and LGM as archived in

59 sediments at the northern and southern ends of Denmark Strait. Active sediment

60 deposition ceased on the Kangerlussuaq Trough Mouth Fan ca. $15.3 \mathrm{ka}{ }^{14} \mathrm{C}$ BP (Andrews

61 et al., 1998; Dunhill, 2005) and retreat to the present outer coast occurred prior to

62 deposition of the Vedde tephra (Jennings et al., 2006). Geophysical data from the

63 Kangerlussuaq Trough, E Greenland (Dowdeswell et al., 2010; Stein, 1996), and from the

64 West Iceland shelf (Syvitski et al., 1999) indicate that there are sites where pre Last

65 Glacial Maximum (LGM) sediments exist, but no such sites have been successfully

66 cored. Syvitski et al (1999), Norddahl and Ingolfsson (2015), and Petursson et al. (2015)

67 argued that the Iceland Ice Sheet retreated rapidly driven by a rapid rise in relative sea

68 level. Jennings et al. (2006) presented evidence for a rapid retreat of the Greenland Ice

69 Sheet under the influence of subsurface Atlantic Water from marine cores along

70 Kangerlussuaq Trough (KT, Fig. 1A). Thus evidence for rapid ice retreat has been

71 presented for both the Greenland and Iceland ice sheets citing different reasons for the 
72 retreat and modeling studies of deglaciation (Patton et al., 2017; Tarasov and Peltier,

73 2002) do not necessarily focus on all multi-proxy evidence. However, in order to

74 understand the forcing mechanism(s) driving ice sheet retreat, the radiocarbon dates have

75 to be adjusted by an ocean reservoir correction that probably varied both temporally and

76 spatially (Stern and Lisiecki, 2013).

77 The purpose of this paper is to use the paleoceanographic records from sites on

78 either side of the Denmark Strait for the time period between deglaciation and deposition

79 of the Vedde tephra ca $12.1 \pm$ cal ka BP in order to explore the potential drivers of ice

80 sheet retreat and to test for the synchronicity of Iceland and Greenland ice sheet retreat.

81 Our focus is on determining conditions during deglaciation, and especially the evidence

82 pertaining to the presence of sea ice and icebergs, and whether we can detect evidence for

83 ocean forcing, which may explain some of the differences between field and modeling

84 data (Lecavalier et al., 2014; Sinclair et al., 2016). The cores are from the N Iceland

85 Húnaflói and Djúpáll troughs, and the E Greenland Kangerlussuaq Trough (Fig. 1A,

86 Tables 1 and 2). Although evidence for ice retreat has been presented separately for both

87 the Greenland and Iceland ice sheets, here we examine the combined regional evidence

88 across Denmark Strait using multiple proxy data, with an emphasis on reconstructing

89 deglacial environmental conditions by the use of sea ice biomarkers, foraminifera, light

90 oxygen isotope data, and sediment properties. Biomarker and sediment mineralogy are

91 new here, whereas the other variables have been reported previously. Data from

92 PO175/1-5 (Mienert, 1990) have not been previously published. Of particular interest,

93 given the evidence for present-day ocean warming impacting the retreat of Greenland

94 tidewater glaciers (Andresen et al., 2011, 2012; Holland et al., 2008), is whether the rapid 
95 retreat of the ice sheets in our area can also be attributed to the incursion of Atlantic

96 Water (Jennings et al., 2006; Knudsen et al., 2003) or if there are other important factors.

97 Regardless of the exact chronology (see below) the sequence of events and regional

98 variations will remain intact.

\section{Background to study region}

100 Atlantic Water in the form of the Irminger Current flows as the surface current northward

101 along the West Iceland shelf and splits into two branches, one of which flows eastward

102 along the inner $\mathrm{N}$ Iceland shelf, whereas the other branch swings south and is present as

103 an intermediate water mass in the large E and SE Greenland troughs (Fig. 1A) (Andresen

104 et al., 2011; Jennings et al., 2011; Kraus, 1958; Syvitski et al., 1996). On the East

105 Greenland shelf the surface current, the East Greenland Current, consists of a cold,

106 relatively low salinity water mass derived from the Arctic Ocean: the East Iceland

107 Current is a branch of this current (Fig. 1A). Under present conditions there is a

108 pronounced tongue of cold surface water that extends to the east of Iceland (Siedov et al.,

109 2016). Sea ice can be present on the Iceland shelves (Divine and Dick, 2006; Ogilvie,

110 1992; Ogilvie and Jonsdottir, 2000) bringing in driftwood from Siberia (Eggertsson,

111 1993; Hellmann and al., 2015), while on the East Greenland shelf sea ice is present for

112 many months of the year (Hastings, 1960). There are no tidewater glaciers on Iceland

113 today whereas on E Greenland there are many tidewater glaciers contributing icebergs

114 onto the inner shelf (Bigg, 1999; Seale et al., 2011).

115 Our study area lies across the Iceland-Greenland Ridge (Larsen, 1983). Iceland is

116 composed of mid-Tertiary to Recent basalt and other extrusive volcanics (Hardarson et

117 al., 2008), in which the occurrence of quartz and high-pressure feldspars is non-existent 
118 or rare. The occurrence of quartz on the Iceland shelf has been used as an indicator of the

119 incursion of drift ice (i.e. icebergs and sea-ice) (Eiriksson et al., 2000; Moros et al., 2006;

120 Thors, 1974). The bedrock geology on the East Greenland side of Denmark Strait is

121 more complex, with a large $\left(60,000 \mathrm{~km}^{2}\right)$ outcrop of early Tertiary basalt between

122 Kangerlussuaq Fjord and the southern coast of Scoresby Sund (Brooks and Nielsen,

123 1982; Brooks, 2008) (Fig. 1A). Cretaceous sandstones and shales exposed in the fjords

124 (Larsen et al., 1999), and Precambrian basement granite gneisses that form most of the

125 hinterland bedrock (Henriksen, 2008), are rich in quartz and k-feldspars which are

126 common components of late Quaternary marine sediments (Andrews et al., 2014, 2015).

127 Analysis of seafloor surface sediments from the N Iceland shelf indicated that

128 quartz and the sea ice biomarker $\operatorname{IP}_{25}$ (Belt et al, 2007) are present and are well correlated

129 with each other, but both are absent in sediments from the W and SW Iceland shelf

130 (Cabedo-Sanz et al., 2016). A paper by Xiao et al. (2017) was recently published on the

131 variations in $\mathrm{IP}_{25}$ in core MD99-2272 just to the east of our B997-326 site and at the same

132 site as HM107-05 (Fig. 1).

\section{Methods}

134 The cores (Table 1) were obtained on cruises of the Poseidon (1991) (Mienert, 1990), Jan

135 Mayen (1996) (Hald, 1996), Bjarni Scemundsson (1997) (Helgadottir, 1997) and Marion

136 Dufresne (1999) (Labeyrie et al., 2003). Detailed descriptions of the methods are given

137 as Supplemental Material and the data are available from Pangeae (www.pangeae.de; see

138 Andrews, Cabedo Sanchez, et al., 2017b). Counts of the $>2 \mathrm{~mm}$ fraction (Grobe, 1987)

139 are a measure of ice-rafting by icebergs, and the Malvern grain-size spectra (Suppl.

140 Material) also provide evidence on the mode of sediment transport and deposition 
141 (Jonkers et al., 2012). The weight \% of quartz on the Iceland Shelf provides a measure of

142 the importation of far-travelled ice-rafted sediments (Andrews, 2009; Eiriksson et al.,

143 2000) whereas calcite wt\% is a measure of marine productivity (Thordardottir, 1984,

144 1986). Regional assessments of oceanographic controls on foraminifera species

145 (Jennings and Helgadottir, 1994; Jennings et al., 2004a; Rytter et al., 2002), stable

146 isotope values (Smith et al., 200; Azetsu-Scott and Tan, 1997), and the sea ice biomarker

$147 \quad \mathrm{IP}_{25}$ (Cabedo-Sanz et al., 2016) provide critical information on paleoceanography.

148 Marine Isotope Stage 2 (MIS2 \& 1) radiocarbon dates: INSTAAR Date Lists

149 (Dunhill et al., 2004; Manley and Jennings, 1996; Quillmann et al., 2009; Smith and

150 Licht, 2000; Andrews et al., in prep) contain 82 dates on marine carbonates (shells and

151 foraminfera) $\geq 12.0{ }^{14} \mathrm{C} \mathrm{ka} \mathrm{BP}$ from the region. Additional dates on near surface

152 planktonic foraminifera, benthic foraminifera, molluscs, and mixed benthic and

153 planktonic foraminifera have been obtained from other papers (e.g. Knudsen et al., 2003,

154 2004)(Suppl. Table 1). Many of the dates noted above and in Supplemental Table 1 were

155 used in the ice sheet modeling study (Patton et al., 2017, see their Table 1). Note that we

156 will refer to the ${ }^{14} \mathrm{C}$ date without marine reservoir correction as ${ }^{~}{ }^{14} \mathrm{C}$ ka $\mathrm{BP}$ " and the

157 calibrated dates, after correction, as "cal ka BP." We focus on cores that penetrated a

158 basal diamicton or have a robust chronology (Fig. 1, Tables 1 and Suppl. Table 1). We

159 do not attempt to "tune" our data to other records, such as the Renland Ice Cap (Fig. 1A),

160 as such a process can result in circular reasoning (Blaauw, 2012).

$161{ }^{14} \mathrm{C}$ dates from core tops on the Kangerlussuaq Trough Mouth Fan date $\sim 15$ to 16

$162{ }^{14} \mathrm{C}$ ka BP (Andrews et al., 1998; Dunhill, 2005) (Fig. 1B) and evidence from NE and W

163 Greenland indicates that the Greenland Ice Sheet started to retreat shortly after the LGM 
164 (O’Cofaigh et al., 2004; Jennings et al., 2017). There are many dates on either side of

165 Denmark Strait range between 12 and $15{ }^{14} \mathrm{C}$ ka BP (Fig. 1B) and bracket the dates for

166 deglaciation. Cosmogenic dates on terrestrial outcrops from either side of Denmark

167 Strait (Brynjolfsson et al., 2015; Dyke et al., 2014; Principato et al., 2006; Sinclair et al.,

168 2016), tephra identifications (Andrews et al., 2008; Jennings et al., 2002, 2014), and ${ }^{14} \mathrm{C}$

169 dates on raised marine deposits (Norðdahl and Ingolfsson, 2015), indicate that the ice

170 sheets retreated to the present coastlines by the time of the Vedde tephra ca $10.6{ }^{14} \mathrm{C}$ ka

171 BP (Lecavalier et al., 2014; Lohne et al., 2013). On Figure 1B we plot the basal ${ }^{14} \mathrm{C}$ dates

172 and whether the cores penetrated basal diamictons (Dmm) (Eyles et al., 1983). We also

173 plot the location of cores JM96-1225 and -1228 where the $N$. pachyderma (s) $\delta^{18} \mathrm{O}$

174 records (Fig. 2) indicate a rapid decrease of $\sim 1.5 \%$ from LGM values of $\sim 4.5 \%$ to $3.5-$

$1753 \%$ (Hagen, 1999a; Hagen and Hald, 2002). The interpolated ${ }^{14} \mathrm{C}$ ages of the $\delta^{18} \mathrm{O}$

176 transition in these cores is $\sim 13.9$ and $15.6{ }^{14} \mathrm{C}$ ka BP. South of our study area the $\delta^{18} \mathrm{O}$

177 transition in core DS97-7P (Kuijpers et al., 2003) $\left(63.523^{\circ} \mathrm{N},-38.658^{\circ} \mathrm{W}, 1843 \mathrm{~m} \mathrm{wd}\right)$ is

178 dated at $13.7{ }^{14} \mathrm{C}$ ka BP. These rapid changes in the $\delta^{18} \mathrm{O}$ could be caused by either the

179 input of isotopically light meltwater due to global ice sheet mass loss (Clark et al., 2004;

180 Lambeck et al., 2014; Peltier et al., 2015; Vasskog et al., 2015; Bigg et al., 2011), or by

181 the influx of warm Atlantic Water (Jennings et al., 2006; Knudsen et al., 2003). .

182 The "unknown" element in establishing a chronology for events is the value(s) for

183 the ocean reservoir correction, $\Delta \mathrm{R}$, although the stratigraphic sequence of events in our

184 cores will remain unaltered. There is evidence for variations in $\Delta \mathrm{R}$ during MIS2 in the

185 northern North Atlantic of up to $1000 \mathrm{yr}$ (Butzin et al., 2005; Sarnthein et al., 2015;

186 Thornalley et al., 2015; Stern and Lisiercki, 2013); however, dates associated with the 
187 Vedde and Saksunarvatn tephras, show that no large-scale $\Delta \mathrm{R}$ correction is required

188 across the Pleistocene/Holocene transition (Andrews et al., 2002a; Jennings et al., 2002,

189 2014). Published calibrations have used a $\Delta \mathrm{R}$ of $0-400 \mathrm{yr}$ (e.g. Jennings et al., 2006;

190 Knudsen et al., 2003; Patton et al., 2017) but we recognize that two alternative arguments

191 can be used to proceed from ${ }^{14} \mathrm{C}$ dates to calibrated dates, and thus we are forced to work

192 within the constraints of a multiple hypothesesis framework (Chamberlin, 1890). Many

193 estimates of larger $\Delta \mathrm{R}$ 's are based on correlations between the marine and Greenland Ice

194 Sheet isotopic records---this requires a close linkage between a climate record from an

195 elevation of $\sim 3 \mathrm{~km}$ and a near-surface marine record. The alternative is that the near

196 surface marine $\delta \delta^{18} \mathrm{O}$ record was responding to freshwater forcing linked to Heinrich

197 events (Bigg et al., 2011) that is dated ca 17.5 cal ka BP (Bigg, 2016; Bigg et al., 2011).

198 A similar degree of change in $\delta^{18} \mathrm{O}$ was noted at the $\mathrm{H}-1$ onset in the Labrador Sea

199 (Andrews et al., 1994) associated with a massive freshwater outburst from Hudson Strait

200 (Hesse and Khodabakhsh, 2016). Support for an earlier, hence small $\Delta \mathrm{R}$, also comes

201 from the detailed identification of tephras in core PS2644 (Voelker and Haflidason, 2015)

202 (not shown---just north of B997-326 (Fig. 1; 67.866º N, 21.765 W, $777 \mathrm{~m} \mathrm{wd}$ ); the

203 resulting depth/age model indicates that the abrupt $\delta^{18} \mathrm{O}$ transition in $N$. pachyderma $\mathrm{s}$

204 occurred $\sim 18$ cal ka BP.

205 On Figure 1C (and in Suppl. Table 1) we show the calibrated dates with a $\Delta \mathrm{R}$ of 0 206 (we used Oxcal (Bronk Ramsey, 2008)). This results in deglaciation dates of between 15 207 and $17 \mathrm{cal} \mathrm{ka} \mathrm{BP}$ and the $\delta^{18} \mathrm{O}$ transition in JM96-1225 at $\sim 16.2$ cal ka BP indicating that 208 deglaciation was coeval with or immediately post-Heinrich event 1 sensus stricto 209 (Hemming, 2004; Hesse and Khodabakhsh, 2016). However, given the Greenland ice 
210 cores $\delta^{18} \mathrm{O}$ records (Vinther et al., 2008; Rasmussen et al., 2014) and regional marine

$211 \delta^{18} \mathrm{O}$ records (Thiagarajan et al., 2014) the abrupt $\delta^{18} \mathrm{O}$ decrease in JM96-1225 (Fig. 2)

212 may date from the Bolling/Allerod (B/A) transition at 14.7 cal ka BP (Rasmussen et al.,

213 2014). If the assumption is made that that the marine $\delta^{18} \mathrm{O}$ transition is coeval with is

214 event, then a larger $\Delta \mathrm{R}$ is required. In order to derive approximate calibrated radiocarbon

215 dates for this second alternative hypothesis we use a $\Delta \mathrm{R}$ of $1000 \pm 200$ for dates $\sim 14{ }^{14} \mathrm{C}$

$216 \mathrm{ka} B P$ and a $\Delta \mathrm{R}$ of $0 \pm 200$ for dates $\sim 10.7{ }^{14} \mathrm{C}$ ka BP. We linearly interpolated between

217 these two $\left(\Delta \mathrm{R}\right.$ decrease of $\left.303 \mathrm{yr} \mathrm{ky}^{-1}\right)$ in order to obtain a calibrated date. This approach

218 has its limitations, but it serves to provide an internally consistent data set (Suppl. Table

219 1Table 2). These calibrated basal dates (Fig. 1C,) indicate deglaciation between $\sim 13$ and

22015 cal ka BP with median age estimates $\sim 13.8$ cal ka BP compared to $\sim 15$ cal ka BP with

221 a $\Delta \mathrm{R}=0$. For cores MD99-2264 and JM96-1213 we developed depth/age models

222 (Blaauw and Christen, 2011) for the two alternative $\Delta$ Rs (Suppl. Material and Suppl. Fig.

$2231)$.

\section{Results: Core sites and records}

225 We first summarize the analysis of the regional grain-size data and then present these and

226 other proxy data on a core-by-core basis, although the available data are not identical

227 from core to core. Our reporting of the $\delta^{18} \mathrm{O}$ on foraminifera is not corrected for vital

228 effects or relative sea level (e.g. Smith et al., 2005). For consistency with earlier papers,

229 we will initially refer to the calibrated dates with $\Delta \mathrm{R}=0$, but with an understanding that

230 these estimates are "less than or equal to." Supplemental. Table 1 contains all calibrated

231 estimates. Data embedded in Figures 3,4, 6 and 7 are archived (www.Pangeae.de). 
Grain-size spectra: Sediment grain-size distributions are important indicator of

233 the mode of sediment erosion, transportation, and deposition (Prins et al., 2002; Weltje

234 and Prins, 2007). Rapid retreat of ice sheets and tidewater ice streams is often marked

235 by massive ice-rafted debris (IRD) signal (Andrews, 2000; Bond et al., 1992), but it can

236 also be signaled by meltwater dominated sedimentation (Hesse and Khodabakhsh, 2016).

237 Grain-size modes (GSMs) (Andrews et al., 2016; Perner et al., 2016) were

238 obtained using k-mean fuzzy clustering (Minasny and McBratney, 2002) on the logratio

23942 transformed fractions (Aitchison, 1986)---we did not exclude the coarse sand (IRD

240 component) (Hass, 2002). Fuzzy clustering allows samples to be mixtures of the main

241 GSMs. The degree of mixing, termed the "confusion index (CI)", varies between 0 (a

242 single cluster membership — no confusion) to a maximum of 1 . Gradistat data on the

243 samples indicated that many of the samples were polymodal, suggesting transport by

244 more than one process (Curry, 1960). The performance indicators (Fig. 3A) distinguished

2453 discrete GSMs. The GSM designations are robust as the confusion index is generally

246 low with only $10 \%$ having significant contributions $(\mathrm{CI}>0.2)$ from more than one GSM

247 (Fig. 3B). The average grain-sizes were computed for each of the 3 GSM's (Fig. 3C) and

248 indicate that the majority of the samples (GSM \#C, $\mathrm{n}=119)$ are classified as poorly

249 sorted medium silts. The average GSM \#A $(n=21$, Fig. 3 C) is a very poorly sorted, very

250 coarse silt, and the average GSM \#B $(n=22)$ is a coarse silt. A bi-plot of mean grain-

251 size versus sorting supports the 3-fold discrimination of the grain-size spectra, although

252 indicating substantial variability in the range of sorting in GSC \#C (Fig. 3D) as does a

253 plot of the percentages of medium sand versus medium silt (Fig. 3E). The samples

254 classified as GSM \#C are very poorly sorted with coarser grain-size represent fine- 
255 grained glacial marine diamictons. Ice-rafting of medium and coarser sand is evident in

256 most of the GSM \#C as shown by the positive skewness and $500 \mu \mathrm{m}$ size mode (Figs. 3C

257 and 3F). Additional commentary on the GSMs is reserved for the discussion of the

258 individual core data (below Figs 4, 6 and 7). In these figures under "Lithology" we plot

259 the lithofacies and the descriptive name for the sediment, such as "medium silt," for those

260 sections of the cores where we have grain size data.

261 North Iceland, Reykjafjarðaáll Trough, core B997-326PC: The Húnaflói/

262 Reykjafjardaáll Trough (HT, Fig. 1A) provided a bathymetric outlet for a major ice

263 stream that flowed northward to the Iceland Sea (Bourgeois, 2000; Hubbard, 2006; Patton

264 et al., 2017, Principato et al.,2016). Core B997-326PC1 (Fig. 4) lies just south of the

265 average AD 1870-1920 April limit of sea ice (Divine and Dick, 2006) (Fig. 1A). Several

266 cores on the northern limit of the trough (B997 -323, -326) penetrated a matrix supported

267 fossiliferous diamicton (Dmm), with dates between 25 and $44{ }^{14} \mathrm{C}$ ka BP (Andrews and

268 Helgadottir, 2003). The contact between the basal diamicton and the overlying glacial

269 marine sediments (Fig. 4) is dated $13,8 \pm 0.2{ }^{14} \mathrm{C}$ ka BP $(16.2 \pm 0.3$ cal ka BP (Suppl.

270 Table 1). A Borrobol-type basaltic tephra was tentatively identified at $140 \mathrm{~cm}$ in B997-

$271326 \mathrm{PC} 2$ and correlated with similar tephras just above the basal diamictons in B997-326,

$272-332$ and -323 (Andrews and Helgadottir, 2003; see www.noaa.gov/paleo). The Vedde

273 tephra may be present at $125 \mathrm{~cm}$ (Andrews and Helgadottir, 2003). A date at $18 \mathrm{~cm}$ of

$2749.7 \pm 0.3 \mathrm{cal} \mathrm{ka} \mathrm{BP}$ indicates that the core either did not recover most of the Holocene or

275 has a compressed Holocene record.

276 Counts of the $>2 \mathrm{~mm}$ (IRD) fraction indicate consistent ice-rafting over the

277 interval from $\sim 16$ to 9.8 cal ka BP (Fig. 4). Nearly all the grain-size spectra between the 
278 base and $125 \mathrm{~cm}$ are classified as GSM \#C (Fig. 3) with only two samples classified as

279 \#A. The qrtz wt $\%(\leq 1 \%)$ is much lower than the present-day input $(\sim 6 \mathrm{wt} \%)$ (Andrews

280 and Eberl, 2007), probably representing the dominance of local quartz-poor sediments.

281 Calcite and total organic carbon (TOC) (Fig. 4) also remain low until the uppermost

282 centimeters, which date from the last 1 cal ka BP (Andrews and Helgadottir, 2003).

283 Although the sea ice biomarker $\mathrm{IP}_{25}$ was often present, it was generally not above the

284 limit of quantification. However, the co-occurring sea ice biomarker $\mathrm{C}_{25: 2}$, is extremely

285 well correlated with IP $_{25}$ on the North Iceland shelf (NIS) (Massé et al., 2011) and could

286 be readily quantified, although its concentration remained low throughout the record.

287 Foraminifera assemblage data in B997-323, which lies seaward of B997-326 (Fig.

288 1A), were reported in Andrews and Helgadottir (2003). The core recovered a basal

289 diamicton that extended from the base of the core to $80 \mathrm{~cm}$. The planktonic foraminifera

290 numbers reach values of 100/g during deglaciation and are associated with relatively

291 heavy $\delta^{18} \mathrm{O}$ values (3.5-4.0\%o) (Fig. 10 in Andrews and Helgadottir, 2003) suggesting

292 deglaciation occurred early in the glacial/deglacial transition (e.g. Fig. 2). Immediately

293 above the basal diamicton the benthic foraminifera show high percentages $(\sim 20 \%)$ of the

294 chilled Atlantic Water species Cassidulina neoteretis (Jennings and Helgadottir, 1994),

295 indicating that the deglaciation was associated with the incursion of Atlantic Water.

296 Sparse stable isotope data were obtained on $\delta^{18} \mathrm{O} N$. pachyderma that showed a sharp

297 increase in $\delta^{18} \mathrm{O}$ to $3.8 \%$ at $60 \mathrm{~cm}$ and that Andrews and Helgadottir (2003) tentatively

298 attributed to the Younger Dryas (YD) cold event (12.8 to $11.5 \mathrm{cal} \mathrm{ka} \mathrm{BP).}$

299 NW Iceland, Djúpáll Trough: Djúpáll is a shallow trough ( 230 m wd) that extends WNW

300 from Ísafjarðardjúp to Denmark Strait (Fig. 1A). An independent ice cap (Hoppe, 1982; 
301 Norðdahl, 1990) may have existed over NW Iceland and been separated from the main Iceland

302 Ice Sheet during the LGM. A large ridge, interpreted, as a moraine lies seaward of the cores we

303 discuss; the trough contains a large drift deposit (Fig. 5A) (Geirsdóttir et al., 2002; Ólafsdóttir,

304 2004). Publications on cores from this drift have focused on the last 12 cal ka BP (Andresen et

305 al., 2005; Andrews et al., 2002b, 2013; Ólafsdóttir et al., 2010; Quillmann, 2006; Quillmann et

306 al., 2010). However, several cores in Djúpál1, JM96-1234GC, MD99-2264, and B997-336PC

307 (Andrews et al., 2008; Geirsdóttir et al., 2002), contain ${ }^{14} \mathrm{C}$ dates older than the Vedde tephra

308 (Suppl. Table 1).

309 Core B997-338PC. This core is situated on the flank of the Djúpáll sediment

310 drift (Fig. 5A). Some of the radiocarbon dates in an initial paper on B997-338PC were

311 incorrect (Andrews et al., 2002b, 2013), probably because of the reworking of

312 foraminifera from the pre-LGM diamicton. The revised chronology is based on two

313 radiocarbon dates on small, articulated shells associated with rhyolithic tephras (Andrews

314 et al., 2013) (Fig. 6A). The two rhyolithic tephras, some $100 \mathrm{~cm}$ apart (Suppl. Table 2),

315 might indicate Borrobol-type (BT) tephras (Andrews et al., 2013; Davies et al.,2004;

316 Lind et al., 2016) and thus not in keeping with $\Delta \mathrm{R}=0$; however, two rhyolithic tephras

317 were noted in the NGRIP core and dated 15.2 and 15.5 cal ka BP (Mortensen et al., 318 2005).

319 The upper $20 \mathrm{~cm}$ of core B997-338PC consists of reworked Vedde ash (Fig. 5A) 320 thus consistent with the ${ }^{14} \mathrm{C}$ date of $11.56 \pm 0.17 \mathrm{ka} \mathrm{BP}$ from $21 \mathrm{~cm}$ (Suppl. Table 1). The 321 core (Fig. 6A) consists of a basal diamicton of compacted overridden glacial marine 322 sediments (dry densities of $\sim 1.5 \mathrm{~g} / \mathrm{cm}^{3}$ ), overlain by poorly sorted, sandy mud or muddy 323 sand $\left(\sim 1 \mathrm{~g} / \mathrm{cm}^{3}\right)$ with some coarse IRD (Chesley, 2005); glacial marine deposition started 
$324 \sim 15$ cal ka BP. In detail, the GSMs are dominated by \#C with an upper interval of \#B

325 (Figs. 3 and 6A). The basal diamicton samples are classified as GSM \#C, and they

326 comprise the very poorly sorted component (Fig. 3D). Sediment mineralogy is

327 dominated by local basalt sources and the qrtz wt $\%$ is very low $(<1 \%)$, hence there is

328 little evidence for a contribution by ice-rafting from Achaean/Paleoproterozoic Greenland

329 bedrock. Age estimates $\left({ }^{39} \mathrm{Ar} /{ }^{40} \mathrm{Ar}\right)$ on basalt IRD clasts do, however, indicate that some

330 clasts were derived from the E Greenland early Tertiary outcrop (Principato, 2003;

331 Principato et al., 2006). The sea ice biomarkers $\mathrm{IP}_{25}$ and $\mathrm{C}_{25: 2}$ were generally below the

332 limits of detection, although $\mathrm{C}_{25: 2}$ could be quantified in a few cases indicating limited

333 occurrence of sea ice.

334 The modest levels of calcite \% (Fig. 6A) indicate there was some marine

335 productivity. The foraminifera consist of sparse planktonic numbers and a fauna

336 dominated by species associated with glacial marine conditions, notably Cassidulina

337 reniforme and Elphidium excavatum f. clavata, which also are the main species in the

338 modern fauna (Jennings et al., 2004a). The chilled Atlantic Water species C. neoteretis

339 occurs in low percentages (Fig. 6A). Sparse stable isotope data were obtained on

340 Cibicides lobatulus, a common epifaunal species, that occurs in current dominated

341 environments (Jennings et al., 2004b) and which showed $\delta^{18} \mathrm{O}$ ratios $\sim 2 \%$ during

342 deglaciation.

343 Core MD99-2264 was retrieved from the center of the Djúpáll drift (Geirsdóttir et

344 al., 2002; Olafsdottir, 2004) (Fig. 5A). Estimates of modern (last 2-3 decades) wt $\%$

345 quartz, $\mathrm{IP}_{25}$, and $\delta^{18} \mathrm{O} N$. pachyderma (s) were obtained on the accompanying box core

346 MD99-2263 of 2\%, $0.004 \mu \mathrm{g} / \mathrm{g}$, and 2.2\%o respectively (Andrews et al., 2009). The 
347 Vedde tephra was identified at $11.8 \mathrm{~m}$ depth. Articulated shells in the basal diamicton

348 Unit A, Fig. 6B) have finite ${ }^{14} \mathrm{C}$ ages of $\sim 53 \mathrm{ka} \mathrm{BP}$, whereas dates above a rhythmite unit

349 (Unit C) range in age between 15.7 and $\sim 12.5$ cal ka BP (Figs. $6 \mathrm{~B}$ ). This core has a very

350 high rate of sediment accumulation allowing for unsurpassed detail of events between

351 deglaciation and deposition of the Vedde tephra (Suppl. Fig. 1). Rates of accumulation

352 averaged $200 \mathrm{yr} / 100 \mathrm{~cm}$ or $125 \mathrm{yr} / 100 \mathrm{~cm}$ depending on the chosen $\Delta \mathrm{R}$ (Suppl. Table 1,

353 Fig. 6B). This, however, does mean that some elements of the record can be diluted

354 especially those we express in percents/g. This core was not included in Patton et al.

355 (2017) paper.

356 During the initial deglaciation coarse IRD deposition occurred (Fig. 6B, Unit B).

357 The sediment between 11 and $15 \mathrm{~m}$ (Unit D) varied between sand to clayey silt, with clay

$358 \%$ s between 4 and $23 \%$. Calcite wt $\%$ was slightly higher in the diamicton than in the

359 overlying sediment but increases slowly and steadily above $20 \mathrm{~m}$ core depth. The same

360 pattern is seen in the wt $\%$ of quartz with values usually less than $2 \%$ below $\sim 16 \mathrm{~m}$. The

361 benthic foraminifera are dominated by the glacial marine Arctic species C.reniforme and

362 E. excavate f. clavata ---these two species are also present in large percentages in the

363 basal diamicton. There are, however, low percentages of the chilled Atlantic Water

364 species $C$. neoteretis as well as the boreal species $C$. laevigata, with a notable but short

365 lived peak in percentages $\sim 1850 \mathrm{~cm}(\sim 14.5 \mathrm{cal}$ ka BP $)$ suggesting relatively warm

366 conditions (Fig. $6 \mathrm{~B}$ ). Stable $\delta^{18} \mathrm{O}$ ratios from the glacial marine sediments $\leq 26 \mathrm{~m}$ on

367 the near-surface planktonic foraminifera N. pachyderma (s), and on the benthic

368 foraminifera C. reniforme (Olafsdottir, 2004) (Fig. 6B) have some outliers. Median $\delta^{18} \mathrm{O}$

369 ratios of $3.0 \%$ and $3.94 \%$ respectively are intermediate in their values relative to ratios 
370 before and after the B/A transition in Denmark Strait (Hagen, 1999a; Ólafsdóttir, 2004).

371 The large difference between the benthic and planktonic $\delta^{18} \mathrm{O}$, especially between 17 and

$37218 \mathrm{~m}$ indicates the presence of a substantial meltwater cap. No $\mathrm{IP}_{25}$ or $\mathrm{C}_{25: 2}$ were detected 373 in samples from 1215 and $1260 \mathrm{~cm}$ depth $(\sim 12.8$ to $13.1 \mathrm{cal} \mathrm{ka} \mathrm{BP})$ and coarse IRD is 374 rare above $20 \mathrm{~m}(\sim 14,3$ cal ka BP $)$.

375 Thus, the 4 basal dates from this area of Iceland range in age between $15.3-16.2$

376 cal ka BP $(\Delta \mathrm{R}=0)$ versus $13.9-14.7 \mathrm{cal} \mathrm{ka} \mathrm{BP}(\Delta \mathrm{R}=\sim 1000)$, and present two

377 potentially quite different scenarios in terms of their glaciological interpretation(s).

378

379 East Greenland: Kangerlussuaq Trough is a deep cross-shelf trough that trends nearly 380 N-S from Kangerlussuaq Fjord to the shelf break south of Denmark Strait (Dowdeswell 381 et al., 2010; Mienert et al., 1992; Stein, 1996). Stein (1996) mapped a series of 382 recessional moraines along the Trough (Fig. 1A).

383 Core PO175/1-5 is a $3.2 \mathrm{~m}$ long core collected from $501 \mathrm{~m}$ water (Mienert, 384 1990), thus from a depth generally below the limit for iceberg scouring (Syvitski et al., 385 2001). A series of short gravity cores were also collected nearby in $\sim 300 \mathrm{~m}$ of water and 386 record conditions over the last ca. $150 \mathrm{yr}$, including both sediment mineralogy and $\mathrm{IP}_{25}$ 387 abundance (Alonso-Garcia et al., 2013). The seismic record across PO175/1-5 (Stein, 388 1996) sampled Unit L of Stein (Fig. 5B). The radiocarbon dates indicate that the bulk of 389 the sediment was deposited between $\sim 17$ and $15{ }^{14} \mathrm{C}$ ka BP (Fig. 7A), although the dates 390 show some reversals, probably from reworking of earlier glacial marine sediments 391 (Suppl. Fig. 1). No grain-size data are available. 
The quartz and calcite wt $\%$ are relatively constant throughout (Fig. 7A) but the

393 quartz is less than $50 \%$ of the wt\% recorded for recent decades in PO176/GKC 9

394 (Alonso-Garcia et al., 2013), whereas the wt $\%$ of calcite has a median value of $0.5 \%$

395 versus $3.3 \%$ in PO176/GKC 9 (i.e. modern). The relatively low quartz wt $\%$ indicates

396 that the sediment was predominantly derived from erosion of the E. Greenland early

397 Tertiary basalt outcrop (Andrews et al., 2015). The foraminifera data show fluctuating

398 numbers/g for both the benthic and planktonic species. What is especially noticeable,

399 given the link with cooled Atlantic Water (Jennings and Helgadottir, 1994), is the

400 presence of $C$. neoteretis, which peaks between 150 and $60 \mathrm{~cm}$, whereas the glacial

401 marine species of C. reniforme and E. excavatum occur in relatively constant percentages

402 although higher in the early part of the record. The $\delta^{18} \mathrm{O}$ data on the near-surface

403 planktonic species N. pachyderma (s) showed relatively little variation about a median

404 value of $2.8 \%$.

405 Both sea ice biomarkers $\left(\mathrm{IP}_{25}\right.$ and $\left.\mathrm{C}_{25: 2}\right)$ show similar trends (Fig. 7A), with low

406 concentration $\sim 300-140 \mathrm{~cm}$ depth, after which, values showed an increasing, but

407 variable trend between $\sim 140-60 \mathrm{~cm}$. At $40 \mathrm{~cm}$, a reduction in $\mathrm{IP}_{25}$ and $\mathrm{C}_{25: 2}$

408 concentrations coincided with a decrease in the quartz data, although there is a generally

409 poor relationship between the biomarkers and quartz wt $\%$. Highest $\mathrm{IP}_{25}$ and $\mathrm{C}_{25: 2}$

410 concentrations were observed during the YD $(\sim 25 \mathrm{~cm})$, before returning to lower

411 concentrations towards the top of the core.

412 JM96-1213GC is a $540 \mathrm{~cm}$ long core that was retrieved in $557 \mathrm{~m}$ of water in the

413 inner/mid- section of the deep Kangerlussuaq Trough (Hald, 1996)(Fig. 1A and 5C).

414 The lithofacies consist of two intervals of diamicton with high IRD, counts and two units 
415 of fine-grained "wispy" laminated muds (Fig. 7B); the basal diamicton (Dmm) is

416 interpreted as a till (Jennings et al., 2002). Four radiocarbon dates were obtained

417 between the top of the diamicton and the Vedde tephra at $\sim 100 \mathrm{~cm}$ (Jennings et al., 2002)

418 (Fig.7B; Suppl. Table 1). The two basal deglaciation dates from cores in the

419 Kangerlussuaq Trough range in age between $\sim 17.6$ and 16.2 cal ka BP $(\Delta \mathrm{R}=0)$ as

420 opposed to 14.7 to 15.8 cal ka BP with the variable $\Delta \mathrm{R}$ (Suppl. Table 1 and Suppl. Fig. 1:

421 Fig. 7B).

422 The GSM modes show cohesive sequences that partly mimic the lithofacies. The

423 basal diamicton and another at $\sim 350 \mathrm{~cm}$ are classified as GSM \#B and (Fig. 3 and 7B),

424 although this mode is not restricted to the Dmm facies, but frequently it coincides with

425 increased IRD input. The YD interval is marked by a marked light $\delta^{18} \mathrm{O}$ peak in the polar

426 species N. pachyderma (s) (Jennings et al., 2006) and a switch to GSMs \#C and A (Figs.

$4273 \& 7 \mathrm{~B})$. The qXRD analysis indicated that calcite was close to the detection limit

428 throughout $(<1 \%)$ whereas quartz had limited variability around a median wt $\%$ of 4.7

429 with a maximum of $7 \%$. The mineralogy is dominated by pyroxene and plagioclase

430 indicating glacial erosion and transport from the nearby early Tertiary basalt outcrop

431 (Andrews et al., 2015).

432 The biomarker data exhibit a generally different trend to that of quartz wt $\%$,

433 although both are lowest below $\sim 420 \mathrm{~cm}$ depth (Fig. 7B). Thus, an alternating profile in

$434 \mathrm{IP}_{25}$ and $\mathrm{C}_{25: 2}$, with lowest values during the $\mathrm{YD}$ and a peak $\sim 80 \mathrm{~cm}$ (Fig. $7 \mathrm{~B}$ ), are not

435 observed in the quartz profile, which exhibits a general increase above $\sim 420 \mathrm{~cm}$.

\section{Discussion}


438 We know little about the stability of the regional ice streams prior to the LGM, although

439 inferences have been made based on nearby deep-sea marine records (Andrews et al.,

440 1998; Hagen and Hald, 2002; van Kreveld et al., 2000). The basal deglaciation dates on

441 cores across Denmark Strait suggest a near synchronous retreat of the Iceland and the

442 East Greenland ice sheets across their respective shelves, although the precise timing is

443 ambiguous because of the uncertainty in $\Delta \mathrm{R}$. Estimates of the rate of retreat from the $\mathrm{E}$

444 Greenland shelf break to Kangerlussuaq Fjord depend on which ocean reservoir

445 correction is used, but in both N Iceland and E. Greenland the ice sheets were back to the

446 present coastline by $\sim 12.2$ cal ka BP (e.g. Patton et al., 2017).

447 The geochemistry of the rhyolithic tephras in B997-338 (Andrews et al., 2013)

448 closely matches those of the Borrobol tephra (Suppl. Table 2). On the N Iceland shelf,

449 Gudmundsson et al (2012) identified a "Borrobol-like" tephra in MD99-2272 and

450 attached an age to it of $14.5 \mathrm{cal} \mathrm{ka}$ BP; this identification was used in the Xiao et al

451 (2017) paper. The similarity coefficient (Sarna-Wojckicki et al., 1984) between the

452 B997-338 tephras and the geochemistry of the type Borrobol (Lind et al., 2016) suggests

453 the closest match with the geochemistry at $90 \mathrm{~cm}$. If correct, this supports the larger $\Delta \mathrm{R}$

454 age estimates. Borrobol-like tephras have not yet been noted from the Kangerlussuaq

455 Trough and in our N Iceland cores the basaltic tephras (Suppl. Table 2) are more difficult

456 to assign to a specific source (Gudmundsson et al., 2012). If the larger $\Delta \mathrm{R}$ correction is

457 correct, and the evidence points toward that conclusion, then the rate of retreat along the

458 Kangerlussuaq Trough (Fig. 1A) approached $\sim 200 \mathrm{~m} / \mathrm{yr}$ and are comparable with recent

459 changes in Greenland ice streams (Khan et al., 2014). 
There is strong evidence that a major change in deep-water circulation at $\sim 15 \mathrm{cal}$

$461 \mathrm{ka} \mathrm{BP}$ resulted in abrupt warming at the onset of the Bølling/Allerød (B/A) interstadial

462 (Thiagarajan et al., 2014; Thornalley et al., 2011). This transition is recognized as a

463 "tipping point" (Turney et al., 2016) in the Northern Hemisphere's climate system

464 (Praetorious and Mix, 2014, 2016) and it is also marked by an abrupt decrease in the

$465 \delta^{18} \mathrm{O}$ of precipitation falling on both the NGRIP site and the nearby Renland Ice Cap

466 (Vinther et al., 2008)(Fig 1A). However, we cannot be absolutely certain that this

467 atmospheric-derived event was coeval with the abrupt decrease in the $\delta^{18} \mathrm{O}$ of $N$.

468 pachyderma (s) in Denmark Strait (Fig. 2), which might rather reflect surface ocean

469 response to freshwater inputs (Bigg et al., 2011),

470 or forcing by atmospheric $\mathrm{CO}_{2}$ variations (Marcott et al., 2014). Glaciological

471 modeling of the retreat histories of the Greenland and Iceland ice sheets have to consider

472 appropriate calibrated age data and for both ice sheets the fall-back position is to use $\Delta \mathrm{R}$

$473=0$ (e..g. Tarasov and Peltier, 2002; Patton et al., 2017).

474 Time dependent processes that influence ice sheet stability include changes in

475 relative sea level, insolation, and ocean warming. On Figure 8A we plot the median

476 calibrated ages and their $95 \%$ age range for the two alternative $\Delta \mathrm{R}$ 's for the deglaciation,

477 and the median dates for the two alternative $\Delta \mathrm{R}$ corrections (Fig. 8B). Note that the

478 Patton et al. (2017) paper used a $\Delta \mathrm{R}$ of $24 \pm 23 \mathrm{yr}$, so their modeled retreats match our

$479 \Delta \mathrm{R}=0$ chronology, and the Sinclair et al (2016) paper also used a $\Delta \mathrm{R}=0$. The

480 difference of $\sim 1.5$ cal ky between the two possible chronologies is most marked at a

481 critical time that would place initial deglaciation close to 16 versus $\sim 14.5$ cal ka BP

482 (Figs. 6B and 7B). Between 20 and 12 cal ka BP global sea level rose by nearly $60 \mathrm{~m}$ 
483 (Lambeck et al., 2014) (Fig. 8C) but rates of change varied dramatically (Fig. 8D).

484 Summer insolation at $65^{\circ} \mathrm{N}$ rose steadily over this period (Fig. 8E). Syvitski et al (1999)

485 and Norðdahl and Ingólfsson (2015) questioned whether the retreat of the Iceland Ice

486 Sheet could have been driven by the increase in sea level associated with deglaciation

487 (Clark et al., 2002)--- rapid increases in sea level occurred at $\sim 17$ and $\sim 15$ cal ka BP (Fig.

488 8D). The argument that rapid deglaciation is associated with relative sea level changes,

489 driven by glacial isostasy and eustasy, is not new (e.g. Hughes, 2011; Tanner, 1965) and

490 has been invoked as an Heinrich event mechanism (Andrews, 1998). However, the local

491 relative sea level (RSL) requires knowledge of the rate of glacial isostatic recovery,

492 which away from the coast (i.e. observations) must be modeled (Peltier et al., 2015; Roy

493 and Peltier, 2015). Models of RSL for our area (Fig. 8C) indicate that glacial isostatic

494 recovery would have resulted in a modest decrease of water depth at ice fronts.

495 Sinclair et al. (2016) suggested that some of the discrepancy between modeling of

496 the post-LGM history of the GIS and field observations, including E Greenland

497 (Lecavalier et al., 2014), might be due to the lack of ocean forcing in the ice sheet

498 models. On Figure 9 we compare our proxies from the deglaciation to $\sim 12$ cal ka BP,

499 and note, where available, the present-day values from our surface/core top samples, and

500 on Figure 10 we illustrate our conclusions in the form of a simplified 3-part scenario.

501 Specific conditions during deglaciation (Figs. 4, 6 and 7) included: 1) significant

502 amounts of coarse $>2 \mathrm{~mm}$ IRD during deglaciation indicating a flux of debris-ladened

503 icebergs, 2) variable sea ice conditions at the East Greenland sites compared to relatively

504 infrequent drift ice occurrence on the N Iceland shelf (as indicated by low sea ice

505 biomarker and qrtz wt\%)---both drift ice proxies are lower than late Holocene values 
506 (Cabedo-Sanz et al., 2016) (Fig. 9C \& F), 3) the presence of C. neoteretis (Fig. 9E)

507 indicates that ice retreat was associated with the incursion of Atlantic Water, 4) $\delta^{18} \mathrm{O}$

508 values of $N$. pachyderma (s), significantly lighter than during the LGM and a noticeable

509 E to $\mathrm{W}$ trend in the $N$. pachyderma (s) $\delta^{18} \mathrm{O}$ signal (Fig. 9D), and 5) significantly higher

510 percentages of calcite off $\mathrm{N}$ Iceland.

511 In our cores the evidence for a distinct YD event is not dramatic, although there is

512 an increase in $\delta^{18} \mathrm{O}$ in B997-323 and -322 (Fig. 4) whereas on the E Greenland shelf the

513 YD is marked by a distinct light $\delta^{18} \mathrm{O}$ signal (Jennings et al., 2006). The YD might also

514 marked by erosional intervals in Djúpáll (Fig. 4, 5, 6 and 7) and be indicated by the

515 increase in quartz and k-feldspar and by the large difference in benthic versus planktonic

$516 \delta^{18} \mathrm{O}$ of $2.93 \%$ in MD99-2264 (Ólafsdóttir 2004), suggestive of a meltwater cap. In this

517 core the grain-size data show that silt and clay \% increased between $\sim 12.7-12.2$ cal ka

518 BP whereas the sand fraction increased to $70-90 \%$ from $\sim 12.2-11.8$ cal ka BP. In JM96-

519 1213GC (Fig. 7B) both sea ice biomarkers decrease to non-detectable values during the

520 YD, which suggests either a lack of sea ice or extensive (perennial) landfast sea ice (Figs.

$5219 \mathrm{C}$ and 10). In a number of other Arctic/sub-arctic records, the YD is often characterized

522 by significantly elevated $\mathrm{IP}_{25}$ abundances (Cabedo-Sanz et al., 2013; Müller et al., 2014;

523 Belt et al., 2015; Méheust et al., 2016); however, ice conditions are somewhat different

524 for the East Greenland sites, insofar as drift ice delivery can be impeded by the presence

525 of near-permanent thick landfast sea ice, such that reduced sea ice biomarker content may

526 be associated with the latter conditions (e.g., Alonso-Garcia et al., 2013). In contrast,

527 higher $\mathrm{IP}_{25}$ (and $\mathrm{C}_{25: 2}$ ) abundances during the $\mathrm{BA}$ and Preboreal periods (e.g., Fig 7B)

528 potentially reflect reduced landfast ice cover with increased drift ice reaching the cores 
529 sites (Alonso-Garcia et al., 2013). Such an explanation cannot be used to account for the

530 low/absent $\mathrm{IP}_{25}$ content for the $\mathrm{N}$ Iceland sites, however, which presumably reflects

531 limited sea ice conditions overall (Fig. 10). In any case, despite the strength of the $\delta^{18} \mathrm{O}$

532 YD signal on the Greenland Ice Sheet (Alley, 2000) the YD cold period (GS 1) is not a

533 striking event in our marine cores.

534 Our study and conclusions are based on a broad geographic coverage of sites (Fig.

5351 and 10) and multi-proxies, but is focused on the area around Denmark Strait. However,

536 a recent biomarker-based study of sea ice conditions, also on the North Icelandic Shelf

537 but further north and east of our core sites, provides further context to our findings.

538 Thus, Xiao et al. (2017) analyzed $\mathrm{IP}_{25}$ and phytoplankton biomarkers in a core (MD99-

5392272 ) located ca. $67^{\circ} \mathrm{N} ; 18^{\circ} \mathrm{W}$, concluding that sea ice conditions were extensive during

540 the Bolling-Allerod, more seasonal during the YD and absent during the early Holocene.

541 Unfortunately, deglacial conditions were not reported from this core. However,

542 differences with our own findings, especially during the Bolling-Allerod and YD, likely

543 reflect the contrasting nature of the sea ice conditions apparent in each study.

544 Specifically, our proxy data almost certainly reflect drift ice conditions (by comparison

545 with modern analogue signatures of biomarkers and qtz content), while the data of Xiao

546 et al. (2017) are interpreted in terms of local biomarker production and thus indicative of

547 a retreating seasonal sea ice margin as observed in many previous $\mathrm{IP}_{25}$-based sea ice

548 reconstructions (e.g., Belt et al., 2015; Berben et al., 2017; Hörner et al., 2016; Müller et

549 al., 2009, 2012; Müller and Stein, 2014; Stein et al., 2017). Common to both studies,

550 however, are generally reduced sea ice conditions during the YD compared to the

551 Bolling-Allerod. Interestingly, the data of Xiao et al. (2017) show a return in $\mathrm{IP}_{25}$ content 
552 during the mid-Holocene - starting ca. $6.5 \mathrm{cal} \mathrm{ka} \mathrm{BP} \mathrm{-} \mathrm{a} \mathrm{feature} \mathrm{that} \mathrm{has} \mathrm{been} \mathrm{reported}$

553 previously from an additional core from the same study site (JR51-GC35) and another

554 core located slightly further west (MD99-2269; ca. $\left.66.38^{\circ} \mathrm{N} ; 20.51^{\circ} \mathrm{W}\right)(\mathrm{Cabedo}-\mathrm{Sanz}$ et

555 al., 2016), both of which were interpreted as reflecting changes to drift ice conditions,

556 especially as $\mathrm{IP}_{25}$ content had previously been shown to be well correlated with

557 observational sea ice records from the region (Massé et al., 2008). Indeed, the presence of

$558 \mathrm{IP}_{25}$ in MD99-2272 during the mid-Holocene (Xiao et al., 2017) is accompanied by

559 increased phytoplankton biomarker content, which contrasts the Bolling-Allerod and YD

560 profiles where high $\mathrm{IP}_{25}$ is accompanied by relatively low phytoplankton biomarker

561 concentrations, a combination consistent with extensive spring sea ice cover (Belt and

562 Müller, 2013; Belt et al., 2015; Berben et al., 2017; Hörner et al., 2016; Müller et al.,

563 2009, 2012; Müller and Stein, 2014; Stein et al., 2017. As such, the $\mathrm{IP}_{25}$ data in MD99-

5642272 likely reflect a shift from local seasonal sea ice occurrence during the Bolling-

565 Allerod and YD to drift ice in the Holocene. Although confirmation of the former is

566 challenging due to absence of any modern analogue for the study region, the various

567 studies highlight significant localized sensitivity with respect to sea ice conditions post-

568 deglaciation.

\section{Conclusions}

570 Figure 10 presents a visual capsule of ice sheet extent and ocean surface conditions for

571 the LGM, initial deglaciation, and the YD. Specific points are:

572 Uncertainty in the $\Delta \mathrm{R}$ correction represents a major limitation in establishing 573 detailed regional marine-based correlations. 
574 Detailed search for, and geochemical fingerprinting of tephras $>11$ and $<15{ }^{14} \mathrm{C}$

$575 \quad$ ka BP would potentially resolve the $\Delta \mathrm{R}$ uncertainty, especially the identification,

576 if present, of the Borrobol tephra and ${ }^{14} \mathrm{C}$ dating of associated sediments. Tephra

577 data from B997-338 points toward the use of a large $\Delta \mathrm{R}$ in calibrating

578 deglaciation dates.

579 The use of the Greenland Ice Sheet's isotopic records as a 1: 1 template for coeval

580 changes in glacier and ocean response potentially ignores the different response

581 time-scales between the atmosphere, oceans, and cryosphere.

582 Deglaciation of the shelves on either side of Denmark Strait was rapid, probably

583 starting $\sim 15$ (or $\sim 17$ ) cal ka BP with ice margins on the outer coasts by Younger

$584 \quad$ Dryas time.

585 Deglaciation was initiated by the incursion of Atlantic Water and aided by a

586 combination of bathymetry and changes in relative sea level.

587 Biomarker, stable isotope, and mineral proxies indicate that differing conditions

588 prevailed on the N Iceland versus E Greenland shelves during deglaciation and

589 the YD with more drift ice on the East Greenland shelf.

590 Further changes in sea ice conditions are evident further east with a general

591 temporal shift from seasonal local sea ice to absent or drift ice conditions during

592 the Holocene.

593 Evidence for a return to glacial conditions during the YD cold event is sparse and $594 \quad$ complex in our marine archives.

\section{Acknowledgements}


597 The research of JTA and AEJ has been supported by several former NSF grants.

598 The contributions from the other authors has been supported by a RANNIS Grant of Excellence

$599 \quad \# 141573-052$ : ANATILS: Integrating paleoclimate reconstructions with modeling to

600 understand abrupt climate change in the northern North Atlantic awarded to A.

601 Geirsdóttir \& G.H. Miller. JTA thanks his colleague Dennis Eberl for his help and

602 instructions over the years of using quantitative mineral identification via XRD. We

603 thank the editor and reviewers for their helpful comments on previous drafts of this

604 manuscript, which have served to clarify both text, tables, and figures.

605

606 The authors confirm that there is no conflict of interest in the submission and content of

607 this manuscript.

608 


\section{Tables}

610 Table 1: Core locations---latitude, longitude, and water depth. Available proxies for the

611 six cores are also listed. Note that because of space on Fig. 1C not all sites could be

612 plotted.

613

614 Suppl. Table 1: Radiocarbon dates, errors and calibrated ages

615

616 Suppl. Table 2: Geochemical data from cores B997-338, --326, and -323 and comparison

617 with the Lipari obsidian standard (Hunt and Hill, 1996)

618 


\section{Figure captions}

620 Figure 1A: Map of the Denmark Strait area showing the primary cores (solid squares),

621 cores noted in the text and providing information (filled stars; Suppl.Table 1). Dotted

622 blue line $=$ average position of the sea ice edge (15\% coverage) April AD 1870-1920

623 (Divine and Dick, 2006). KT = Kangerlussuaq Trough, $\mathrm{H}=$ Húnaflói, the Djúpáll Trough

624 is located at core MD99-2264. Surface Atlantic Currents: Irminger Current = IC, North

625 Iceland Irminger Current (NIIC); cold surface Arctic/Polar Currents: East Greenland

626 Current $=$ EC, East Iceland Current $=$ EIC. B) Map of basal uncorrected ${ }^{14} \mathrm{C}$ dates and

627 whether the core penetrated a basal diamicton (Dmm). Black squares show the two cores

628 with stable isotope records across the glacial/deglacial transition. C) The calibrated ${ }^{14} \mathrm{C}$

629 dates with values based on a $\Delta \mathrm{R}$ of 0 versus the sliding scale $\Delta \mathrm{R}$ estimates (Table 2 ).

630 The number in brackets along Kangerlussuaq Fjord (11.8 cal ka BP) is the average

631 cosmogenic date (Dyke et al., 2014).

632 Figure 2: Neogloboquadrina pachyderma s $\delta^{18} \mathrm{O}$ records from north and south of

633 Denmark Strait (Hagen, 1999) illustrating the transition from glacial to interstadial

634 values, and the differences in the radiocarbon dates that we assume is associated with

635 regional variations in the ocean reservoir correction (see text).

636 Figure 3: Analysis of the grain-size spectra. A) Plot of the 3 performance indictors in

637 FuzMe (Minansy, 2010; Minasny and McBratney, 2002) (MPE= modified partition

638 entropy, FPI = fuzziness performance indicator, $\mathrm{S}=$ Compactness and separation validity

639 function) indicating the optimal solution of 4 Grain-size mode (GSM) clusters; B)

640 Probability plot of the Confusion Index (CI) $(0=$ certainty of cluster membership, $1=$

641 equal mixture of the 3 grain-size modes C) Plot of the average grain-size spectra for the 3 
642 GSMs; D) Plot of the mean grain-size ( $\mu \mathrm{m})$ and sorting; E) Plot of the percentages of

643 medium sand versus medium silt; and F) Plot of aspects of the shape of the grain-size

644 spectra, Skewness versus Kurtosis (Folk and Ward, 1957; Blott and Pye, 2001).

645 Figure 4: Downcore plots of data from B997-326 and -323 (Fig. 1) on the N Iceland

646 shelf (see Tables 1 and 2) for available data and radiocarbon dates. Data are on

647 percentage values unless otherwise noted. Stable isotope data $\left(\delta^{18} \mathrm{O}\right.$ NPs $)$ for $N$.

648 pachyderma (s). Red dashed lines show the possible location of basaltic tephras and

649 solid red lines (also Figures 6 and 7) show the position of rhyolithic tephras (T). The

650 calibrated dates from B997-323 are listed as (cal ka 323).

651 Figure 5: A) Seismic (chirper) plot across the Djúpáll Drift (Geirsdottir et al., 2002;

652 Olafsdottir, 2004). The insert shows the bathymetry and location of the cross-section. B)

653 Seismic section along the outer Kangerlussuaq Trough showing the relative location of

654 the sites for BS1191-K18B/JM96-1216 and 175PO/1-5 in unit L (from Stein, 1996). C)

655 Seismic stratigraphy at the site of JM96-1213GC.

656 Figure 6A \& B: Downcore plots of data from the Djupal Trough, NW Iceland (Fig. 1) A)

657 B997-338 showing the location of the rhyolithic tephras (red dashed lines) and calibrated

658 dates $\Delta \mathrm{R}=0$. B) MD99-2264. The depth/age plots show the models for a $\Delta \mathrm{R}=0$ in blue

659 and the variable $\Delta \mathrm{R}$ in red - the Vedde tephra is indicated by the red dashed line. The

660 vertical dashed line shows depth of the $\sim 14.5 \mathrm{cal} \mathrm{ka}$ BP for either model. The $\delta^{18} \mathrm{O}$ data

661 are for C. reniforme (benthic) (Cr) and N. pachyderma (s) (planktonic)(Nps). The plot

662 (B- $\mathrm{P} \%$ ) shows the $\delta^{18} \mathrm{O}$ difference between the benthic and planktonic paired

663 measurements. 
664 Figure 7A and B: Downcore plots of cores from the Kangerlussuaq Trough (Fig. 1A,

665 Table 1) A) PO175/1-5, and B) JM96-1213. The depth/age plots show the models for a $666 \Delta \mathrm{R}=0$ in blue and the variable $\Delta \mathrm{R}$ in red-the Vedde tephra is indicated by the red 667 dashed line. The vertical dashed line shows depth of the $\sim 14.5$ cal ka BP for either

668 model. The $\delta^{18} \mathrm{O}$ data are on the near-surface planktonic foraminifera N. pachyderma (s).

669 Figure 8: Global and regional parameters operating in the period between 12 and $17 \mathrm{cal}$

670 ka BP. A) Plot of median calibrated ages and the 95\% confidence interval for sites

671 discussed in this paper (Fig. 1, see Table 2) using $\Delta \mathrm{R}=0$ (red) and $\Delta \mathrm{R} \leq 1000 \mathrm{yr}$ (blue).

672 The vertical solid blue and red lines represent the median ages for the basal dates for the 673 two $\Delta$ R options; C) Eustatic sea level (Lambeck et al., 2014) and estimates of relative sea 674 level change (RSL) at specific latitudes and longitudes (Peltier, person. commun. 2016).

675 D) Rate of change of global sea level (C); and E) July Insolation at $65^{\circ} \mathrm{N}$ (Berger and 676 Loutre, 1991);

677 Figure 9: Box plots of surface \& near-surface environment proxies across Denmark Strait 678 (east to west) between 12 to $\sim 15$ cal ka BP--- -numbers give the wt $\%$ of modern samples 679 showing: A) Weight \% quartz; B) Weight \% calcite; and C) IP25; D) $\delta^{18}$ O for the near680 surface polar planktonic foraminifera Neogloboquadrina pachyderma; E) Map of the \% 681 of $C$. neoteretis for the deglacial interval > 12 cal ka BP; F) Diene II.

682 Figure 10: Simplified scenarios of conditions in Denmark Strait at the end of MIS2 and 683 during the initial period of deglaciation. Red triangles represent icebergs and the white 684 patches represent sea ice. Black dots refer to the core locations as listed in Table 1. Red 685 arrows represent warm surface (Atlantic Water) currents and the dark blue represents the 


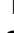

2

3

4

5

6

7

8

9

10

11

12

13

14

15

16

17

18

19

20

21

22

23

24

25

26

27

28

29

30

31

32

33

34

35

36

37

38

39

40

41

42

43

44

45

46

47

48

49

50

51

52

53

54

55

56

57

58

59

60

686 export of cold Polar Water. A) Ice Sheet extent during the LGM; B) conditions during

687 deglaciation, and C) Conditions at the YD interval.

688 


\section{References}

690

691 Aitchison, J., 1986. The statistical analysis of compositional data. Chapman and Hall, 692 London, $416 \mathrm{pp}$.

693 Alley, R.B., 2000. The Younger Dryas cold interval as viewed from central Greenland. 694 Quaternary Science Reviews 19, 213-226.

695 Alonso-Garcia, M., JT, A., Belt, S.T., Cabedo-Sanz, P., Darby, D., Jaeger, J., 2013. A

696 multi-proxy and multi-decadal record (to AD 1850) of environmental conditions on the 697 East Greenland shelf $\left(\sim 66^{\circ} \mathrm{N}\right)$. The Holocene $23,1672-1683$.

698 Andresen, C.S., Bond, G., Kuijpers, A., Knutz, P., Bjorck, S., 2005. Holocene climate 699 variability at multi-decadal time-scales detected by sedimentological indicators in a shelf 700 core NW off Iceland. Marine Geology 214, 323-338.

701 Andresen, C.S., McCarthy, D.J., Dylmer, C.V., Seidenkrantz, M.S., Kuijpers, A., Lloyd, 702 J.M., 2011. Interaction between subsurface ocean waters and calving of the Jakobshavn 703 Isbrae during the late Holocene. Holocene 21, 211-224.

704 Andresen, C.S., Straneo, F., Ribergaard, M.H., Bjork, A.A., Andersen, T.J., Kuijpers, A.,

705 Norgaard-Pedersen, N., Kjaer, K.H., Schjoth, F., Weckstrom, K., Ahlstrom, A.P., 2012.

706 Rapid response of Helheim Glacier in Greenland to climate variability over the past 707 century. Nature Geoscience 5, 37-41.

708 Andrews, J.T., 1998. Abrupt changes (Heinrich events) in late Quaternary North Atlantic 709 marine envrionments: a history and review of data and concepts. Journal of Quaternary 710 Science 13, 3-16.

711 Andrews, J.T., 2008. The role of the Iceland Ice Sheet in sediment delivery to the North

712 Atlantic during the late Quaternary: how important was it? Evidence from the area of

713 Denmark Strait. Journal of Quaternary Science 23`, 3-20.

714 Andrews, J.T., 2009. Seeking a Holocene drift ice proxy: non-clay mineral variations

715 from the SW to N-central Iceland shelf: trends, regime shifts, and periodicities. Journal of 716 Quaternary Science 24, 664-676.

717 Andrews, J.T., Belt, S.T., Olafsdottir, S., Masse, G., Vare, L., 2009. Sea ice and marine 718 climate variability for NW Iceland/Denmark Strait over the last 2000 cal. yr BP. The 719 Holocene 19, 775-784. 
720 Andrews, J.T., Bigg, G.R., Wilton, D.J., 2014. Holocene sediment transport from the

721 glaciated margin of East/Northeast Greenland $\left(67-80^{\circ} \mathrm{N}\right)$ to the N Iceland shelves:

722 Detecting and modeling changing sediment sources Quaternary Science Reviews 91, 723 204-217.

724 Andrews, J.T., Bjork, A.A., Eberl, D.D., Jennings, A.E., Verplanck, E.P., 2015.

725 Significant differences in late Quaternary bedrock erosion and transportation: East versus

726 West Greenland $\sim 70^{\circ} \mathrm{N}$ and the evolution of glacial landscapes. Journal of Quaternary

727 Science 30, 452-463.

728 Andrews, J.T., Cabedo Sanchez, P., Jennings, A.E., Olafsdottir, S., Belt, S.T., Geirsdottir,

729 A., 2017b. Data supplement to: Sea ice, ice-rafting, and ocean climate across

730 Denmark Strait during rapid deglaciation ( $\sim 16$ to $12 \mathrm{cal} \mathrm{ka}$ BP) of the Iceland and

731 East Greenland shelves, http://www.pangeae.de.

732 Andrews, J.T., Cooper, T.A., Jennings, A.E., Stein, A.B., Erlenkeuser, H., 1998. Late

733 Quaternary iceberg-rafted detritus events on the Denmark Strait/Southeast Greenland

734 continental slope $\left(\sim 65^{\circ} \mathrm{N}\right)$ : Related to North Atlantic Heinrich Events? . Marine Geology $735149,211-228$.

736 Andrews, J.T., Dunhill, G., Vogt, C., Voelker, A., 2017a. Denmark Strait during the LGM

737 and MIS3: sediment transport processes and sources: an examination of a D-O

738 hypothesis Marine Geology 390, 181-198.

739 Andrews, J.T., Eberl, D.D., 2007. Quantitative mineralogy of surface sediments on the

740 Iceland shelf, and application to down-core studies of Holocene ice-rafted sediments.

741 Journal of Sedimentary Research 77, 469-479.

742 Andrews, J.T., Erlenkeuser, H., Tedesco, K., Aksu, A., Jull, A.J.T., 1994. Late

743 Quaternary (Stage 2 and 3) Meltwater and Heinrich events, NW Labrador Sea.

744 Quaternary Research 41, 26-34.

745 Andrews, J.T., Geirsdottir, A., Hardardottir, J., Principato, S., Gronvold, K.,

746 Kristjansdottir, G.B., Helgadottir, G., Drexler, J., Sveinbjornsdottir, A., 2002a.

747 Distribution, sediment magnetism, and geochemistry of the Saksunarvatn (10180 $60 \pm$ cal 
748 yr BP) tephra in marine, lake, and terrestrial sediments, NW Iceland. Journal of

749 Quaternary Science 17, 731-745.

750 Andrews, J.T., Hardarddottir, J., Helgadottir, G., Jennings, A.E., Geirsdottir, A.,

751 Sveinbjornsdottir, A.E., Schoolfield, S., Kristjansdottir, G.B., Smith, L.M., Thors, K.,

752 Syvitski, J.P.M., 2000. The N and W Iceland Shelf: Insights into Last Glacial Maximum

753 Ice Extent and Deglaciation based on Acoustic Stratigraphy and Basal Radiocarbon AMS

754 dates. Quaternary Science Reviews 19, 619-631.

755 Andrews, J.T., Hardardottir, J., Geirsdottir, A., Helgadottir, G., 2002b. Late Quaternary

756 ice extent and depositional history from the Djupall trough, off the Vestfirdir peninsula,

757 north-west Iceland: A stacked 36 cal environmental record. Polar Research 21, 211-226.

758 Andrews, J.T., Hardardottir, J., Stoner, J.S., Mann, M.E., Kristjansdottir, G.B., Koc, N., 2003.

759 Decadal to millennial-scale periodicities in North Iceland shelf sediments over the last 12,000 cal

760 yrs: long-term North Atlantic oceanographic variability and Solar forcing. Earth and Planetary

761 Science Letters 210, 453-465.

762 Andrews, J.T., Hardardottir, J., Stoner, J., Principato, S.M., Geirsdottir, A., 2008.

763 Holocene sediment magnetic properties along a transect from Isafjardardjup to Djupall,

764 Northwest Iceland. Arctic, Antarctic, and Alpine Research 40, 1-14.

765 Andrews, J.T., Helgadottir, G., 2003. Late Quaternary ice cap extent and deglaciation of

766 Hunafloaall, NorthWest Iceland: Evidence from marine cores. Arctic, Antarctic, and

767 Alpine Research 35, 218-232.

768 Andrews, J.T., Jennings, A.E., Coleman, C.G., Eberl, D., 2010. Holocene variations in

769 mineral and grain-size composition along the East Greenland glaciated margin (ca 67-

$77070^{\circ} \mathrm{N}$ ): local versus long-distant sediment transport. Quaternary Science Reviews 29,

$7712619-2632$.

772 Andrews, J.T., Stein, R., Moros, M., Perner, K., 2016. Late Quaternary changes in

773 sediment composition in NE Greenland Fjords, Shelf, Slope, and Deep Sea. Boreas 45,

$774 \quad 381-397$.

775 Andrews, J.T., Vogt, C., 2014a. Results of Bulk Sediment X-ray Diffraction Analysis and

776 Quantification of Mineral Phases Based on the RockJock and on the QUAX Quantita-tive

777 Analysis. http://dx.doi.org/10.1594/PANGAEA.830397. doi:10.1594/PANGAEA.830395. 
778 Andrews, J.T., Vogt, C., 2014b. Source to Sink: Statistical identification of regional

779 variations in the mineralogy of surface sediments in the western Nordic Seas $\left(58^{\circ} \mathrm{N}-\right.$

$\left.78075^{\circ} \mathrm{N} ; 10^{\circ} \mathrm{W}--40^{\circ} \mathrm{W}\right)$ ). Marine Geology 357, 151-162.

781 Austin, W.E.N., Wilson, L.J., Hunt, J.B., 2004. The age and chronostratigraphical

782 significance of North Atlantic Ash Zone II. Journal of Quaternary Science 19, 137-146.

783 Azetsu-Scott, K., Tan, F.C., 1997. Oxygen Isotope Studies from Iceland to an East

784 Greenland Fjord: Behavior of Glacial Meltwater Plume. Marine Chemistry 56, 239-251.

785 Belt, S.T., Cabedo-Sanz, P., Smik, L., Navarro-Rodriguez, A., Berben, S.M.P., Knies, J.,

786 Husum, K., 2015. Identification of paleo Arctic winter sea ice limits and the marginal ice

787 zone: optimised biomarker-based reconstructions of late Quaternary Arctic sea ice. Earth

788 and Planetary Science Letters 431, 127-139.

789 Belt, S.T., Masse, G., Rowland, S.J., Poulin, M., Michel, C., and LeBlanc, B. 2007. A novel

790 chemical fossil of palaeo sea ice: IP25. Organic Gechemistry 38: 16-27.

791 Berben, S.M.P., Husum, K., Navarro-Rodriguez, A., Belt, S.T., Aagaard-Sørensen, S.,

792 2017. Semi-quantitative reconstruction of early to late Holocene spring and summer sea

793 ice conditions in the northern Barents Sea. Journal of Quaternary Science.

794 Berger, A., Loutre, M.F., 1991. Insolation values of the climate of the last 10 Million

795 years. Quaternary Science Reviews 10, 297-318.

796 Bigg, G.R., 1999. An estimate of the flux of iceberg calving from Greenland. Arctic,

797 Antarctic, and Alpine Research 31, 174-178.

798 Bigg, G.R., 2016. Icebergs. Their Science and links to Global Change. Cambridge

799 University Press.

800 Bigg, G.R., Levine, R.C., Green, C.L., 2011. Modelling abrupt glacial North Atalntic freshening:

801 Rates of change and their implication for Heinrich events. Global and Planetary Change 79, 176802192.

803 Blaauw, M., 2012. Out of tune: the dangers of aligning proxy archives. Quaternary Science

804 Reviews 36, 38-49.

805 Blaauw, M., Christen, J.A., 2011. Flexible Paleoclimate Age-Depth Models Using an

806 Autoregressive Gamma Process. Bayesian Analysis 6, 457-474. 
807 Blott, S.J., Pye, K., 2001. GRADISTAT: A grain size distribution and statistics package 808 for the analysis of unconsolidated sediments. Earth Surface Processes and Landforms 26, $809 \quad 1237-1248$.

810 Bond, G., Heinrich, H., Broecker, W.S., Labeyrie, L., McManus, J., Andrews, J.T., Huon, 811 S., Jantschik, R., Clasen, S., Simet, C., Tedesco, K., KLas, M., Bonani, G., Ivy, S., 1992.

812 Evidence for massive discharges of icebergs into the glacial Northern Atlantic. Nature $813360,245-249$.

814 Bourgeois, O., Dauteil, O., Van Viet-Lanoe, B., 2000. Geothermal control on ice stream 815 formation: flow patterns of the Icelandic Ice Sheet at the Last Glacial Maximum. Earth 816 Surface Processes and Landforms 25, 59-76.

817 Bronk Ramsey, C., 2008. Deposition models for chronological records. Quaternary 818 Science Reviews 27, 42-60.

819 Brooks, C.K., Nielsen, T.F.D., 1982. The Phanerozoic development of the 820 Kangerdlugssuaq area, East Greenland. Meddelelser on Gronland, Geoscience 9, 1-30.

821 Brooks, K., 2008. A new geologiocal map of East Greenland. Geology Today 24, 28-30.

822 Brynjolfsson, S., Schomacker, A., Ingolfsson, O., Keiding, J.K., 2015. Cosmogenic Cl-36

823 exposure ages reveal a $9.3 \mathrm{ka} \mathrm{BP}$ glacier advance and the Late Weichselian-Early

824 Holocene glacial history of the Drangajokull region, northwest Iceland. Quaternary

825 Science Reviews 126, 140-157.

826 Butzin, M., Prange, M., Lohmann, G., 2005. Radiocarbon simulations for the glacial

827 ocean: The effects of wind stress, Southern Ocean sea ice and Heinrich events. Earth and 828 Planetary Science Letters 235, 45-61.

829 Cabedo-Sanz, P., Belt, S.T., Jennings, A.E., Andrews, J.T., Geirsdottir, A., 2016.

830 Variability in drift ice export from the Arctic Ocean to the North Icelandic Shelf over the 831 last 8,000 years: a multi-proxy evaluation. Quaternary Science Reviews.

832 Castaneda, I.S., Smith, M.L., Kristjansdottir, G.B., Andrews, J.T., 2004. Temporal 833 changes in Holocene del180 records from the northwest and central North Iceland Shelf. 834 Journal of Quaternary Science 19, 1-14.

835 Chamberlin, T.C., 1890. The Method of Multiple Working Hyptheses. Science 15, 754836759. 
837 Chesley, T., 2005. Mineralogy, sediment, and foraminiferal history of Djupall, Iceland:

838 reconstructing a past record, Department of Geological Sciences. University of Colorado,

839 Boulder, p. 62.

840 Clark, P.U., M., M., Mix, A.C., Weaver, A.J., 2004. Rapid rise of sea level 19,000 years

841 ago and its global implications. Science 304, 1141-1144.

842 Clark, P.U., Mitrovica, J.X., Milne, G.A., Tamisiea, M.E., 2002. Sea-level fingerprinting

843 as a direct test for the source of Global Meltwater Pulse 1A. Science 295, 2438-2441.

844 Cook, A.J., Holland, P.R., Meredith, M.P., Murray, T., Luckman, A., Vaughan, D.G.,

845 2016. Ocean forcing of glacier retreat in the western Antarctic Peninsula. Science 353,

846 283-286.

847 Curray, J.R., 1960. Tracing sediment masses by grain size modes, 21st International Geological

848 Congress, Cophenhagen, pp. 119-130.

849 Davies, S.M., Wohlfarth, B., Wastegard, S., Andersson, M., Blockley, S., Possnert, G., 2004.

850 Were there two Borrobol Tephras during the early Lateglacial period: implications for

851 tephrochronology? Quaternary Science Reviews 23, 581-589.

852 Divine, D.V., Dick, C., 2006. Historical variability of the sea ice edge position in the

853 Nordic Seas. Journal of Geophysical Research 111, 1 of 14, doi:10.1029/2004JC002851.

854 Dowdeswell, J.A., Evans, J., Cofaigh, C.O., 2010. Submarine landforms and shallow

855 acoustic stratigraphy of a $400 \mathrm{~km}$-long fjord-shelf-slope transect, Kangerlussuaq margin,

856 East Greenland. Quaternary Science Reviews 29, 3359-3369.

857 Dunhill, G., 2005. Iceland and Greenland margins: A comparison of depositional

858 processes under differnt glaciological and oceanographic settings, Geological Sciences.

859 University of Colorado, Boulder, p. 242.

860 Dunhill, G., Andrews, J.T., Kristjansdottir, G.B., 2004. Radiocarbon Date List X: Baffin

861 Bay, Baffin Island, Iceland, Labrador, and the northern North Atlantic. Occasional Paper

862 No. 56, Institute of Arctic and Alpine Research, UNiversity of Colorado, Boulder, 77 pp.

863 Dyke, L.M., Hughes, A.L.C., Murray, T., Hiemstra, J.F., Andresen, C.S., Rodes, A., 2014.

864 Evidence for the asynchronous retreat of large outlet glaciers in southeast Greenland at

865 the end of the last glaciation. Quaternary Science Reviews 99, 244-259.

866 .Eggertsson, O., 1993. Origin of the driftwood on the coasts of Iceland: A

867 dendrochronological study. Jokull 43, 15-32. 
868 Eiriksson, J., Knudsen, K.L., Haflidason, H., Henriksen, P., 2000. Late-glacial and

869 Holocene paleoceanography of the North Iceland Shelf. Journal of Quaternary Science 15, $870 \quad 23-42$.

871 Eyles, C.H., Eyles, N., Miall, A.D., 1983. Lithofacies types and vertical profile models;

872 an alternative approach to the description and environmental interpretation of glacial

873 diamict and diamictite sequences. Sedimentology 30, 393-410.

874 Folk, R.K., Ward, W.C., 1957. Brazos River bar: a study of the significance of grain size

875 parameters. Journal of Sedimentary Petrology 27, 3.-26.

876 Funder, S., Jennings, A.E., Kelly, M.J., 2004. Middle and late Quaternary glacial limits in

877 Greenland, in: Ehlers, J.a.G., O.L. (Ed.), Quaternary Glaciations-Extent and Chronology,

878 Part II. Elsevier, New York, pp. 425-430.

879 Geirsdottir, A., Andrews, J.T., Olafsdottir, S., Helgadottir, G., Hardardottir, J., 2002. A

$88036 \mathrm{ka}$ record of iceberg rafting and sedimentation from north-west Iceland. Polar

881 Research 21, 291-298.

882 Grobe, H., 1987. A Simple Method for the Determination of Ice-Rafted Debris in

883 Sediment Cores. Polarforschung 57, 123-126.

884 Gudmundsdottir, E.R., Larsen, G., Eiriksson, J., 2012. Tephra stratigraphy on the North

885 Icelandic shelf: extending tephrochronology into marine sediments off North Iceland.

886 Boreas 41, 718-734.

887 Hagen, S., 1999a. North Atlantic paleoceanography and climate history during the last

88870 cal. ka years, Department of Geology. University of Tromso, Tromso, p. 110 pp.

889 Hagen, S., 1999b. North Atlantic Paleocedanography and climate history during the last

$890 \sim 70$ cal. ka years, Department of Geology. University of Tromso, Tromso, Norway, p.

891110.

892 Hagen, S., Hald, M., 2002. Variation in surface and deep water circulation in the

893 Denmark Strait, North Atlantic, during marine isotope stages 3 and 2. Paleoceaography

$89417,13-11$ to $13-16(10.1029 / 2001$ PA000632).

895 Hald, M., 1996. Greenland-Iceland margin cruise 1996. Universityof Tromso, , Tromso, 896 Norway, p. 18.

897 Hardarson, B.S., Fitton, J.G., Hjartarson, A., 2008. Tertiary volcanism in Iceland. Jokull $89858,161-178$. 
899 Hass, C.H., 2002. A method to reduce the influebnce of ice-rafted debris on a grain size

900 record from northern Fram Strait, Arctic Ocean. Polar Research 21, 299-306.

901 Hastings, A.D., 1960. Environment of Southeast Greenland. Quatermaster Research and

902 Engineering Command.

903 Helgadottir, G., 1997. Paleoclimate (0 to >14 ka) of W. and NW Iceland: An

904 Iceland/USA Contribution to P.A.L.E., Cruise Report B9-97. Marine Research Institute

905 of Iceland, Reykjavik.

906 Hellmann, L., al., e., 2015. Timber logging in Central Siberia is the main source for

907 recent Arctic driftwood. Arctic, Antarctic, and Alpine Research 47, 449-460.

908 Hemming, S.R., 2004. Heinrich Events: Massive late Pleistocene detritus layers of the

909 North Atlantic and their global climate imprint. Reviews of Geophysics 42,

910 RG1005/2004.

911 Henriksen, H., 2008. Geological history of Greenland. Geological Survey of Denmark

912 and Greenland, Copenhagen.

913 Hesse, R., Khodabakhsh, S., 2016. Anatomy of Labrador Sea Heinrich layers. Marine

914 Geology 380, 44-66.

915 Holland, D.M., Thomas, R.H., De Young, B., Ribergaard, M.H., Lyberth, B., 2008.

916 Acceleration of Jakobshavn Isbrae triggered by warm subsurface ocean waters. Nature

917 Geoscience 1, 659-664.

918 Hoppe, G., 1982. The Extent of the last Inland Ice Sheet of Iceland. Jökull 32, 3-11.

919 Hubbard, A., 2006. A multidisciplined approach to the reconstruction of Late

920 Weischielian deglaciation of Iceland, in: Knight, P.G. (Ed.), Glacier Science and

921 Environmental Change. Blackwell Publishing, Oxford, pp. 114-119.

922 Hörner, T., Stein, R., Fahl, K., Birgel, D., 2016. Post-glacial variability of sea ice cover,

923 river run-off and biological production in the western Laptev Sea (Arctic Ocean) - A high

924 resolution biomarker study. Quaternary Science Reviews 143, 133-149.

925 Huddard, A., Sugden, D., Dugmore, A., Norddahl, H., Petersson, H.G., 2006. A

926 modelling insight into the Icelandic Last Glacial Maximum ice sheet. Quaternary Science

927 Reviews 25, 2283-2296.

928 Hughes, T., 2011. A simple holistic hypothesis for the self-destruction of ice sheets.

929 Quaternary Science Reviews 30, 1829-1845. 
930 Jennings, A.E., Andrews, J.T., ÓCfoaigh, C., St. Onge, G., Sheldon, S., Belt, S.T., Cabedo-Sanz, 931 P., Hillaire-Marcel, C., 2017. Ocean forcing of Ice Sheet Retreat in Central West Greenland from 932 LGM through Deglaciation. Earth and Planetary Science Letters.

933 Jennings, A.E., Andrews, J.T., Wilson, L., 2011. Holocene environmental evolution of th 934 SE Greenland Shelt north and south of the Denmark Strait: Irminger and East Greenland 935 current interactions. Quaternary Science Reviews 30, 980-998.

936 Jennings, A.E., Gronvold, K., Hilberman, R., Smith, M., Hald, M., 2002. High resolution 937 study of Icelandic tephras in the Kangerlussuaq Trough, southeast Greenland, during the 938 last deglaciation. Journal of Quaternary Science 17, 747-757.

939 Jennings, A.E., Hald, M., Smith, L.M., Andrews, J.T., 2006. Freshwater forcing from the 940 Greenland Ice Sheet during the Younger Dryas: Evidence from Southeastern Greenland 941 shelf cores. Quaternary Science Reviews 25, 282-298.

942 Jennings, A.E., Helgadottir, 1994. Foraminiferal assemblages from the fjords and shelf of 943 Eastern Greenland. Journal Foraminiferal Research 24, 123-144.

944 Jennings, A.E., Syvitski, J.P.M., Gerson, L., Gronvald, K., Geirsdottir, A., Hardardottir, 945 J., Andrews, J.T., Hagen, S., 2000. Chronology and paleoenvironments during the late 946 Weichselian deglaciation of the SW Iceland Shelf. Boreas 29, 167-183.

947 Jennings, A.E., Thordarson, T., Zalzal, K., Stoner, J.F., Hayward, C., Geirsdottir, A., 948 Miller, G.H., 2014. Holocene tephra from Iceland and Alaska Record in SE Greenland 949 Shelf sediments, in: Austin, W.E.N., Abbott, P.M., Davis, S., M., Pearce, N.J.G., 950 Wastegard, S. (Eds.), Marine tephrachronology. Royal Society of London Special 951 publication 398, pp. 157-193.

952 Jennings, A.E., Weiner, N.J., Helgadottir, G., Andrews, J.T., 2004a. Modern

953 foraminiferal faunas of the Southwest to Northern Iceland shelf: Oceanographic and

954 environmental controls. Journal of Foraminiferal Research 34, 180-207.

955 Jonkers, L., Prins, M.A., Moros, M., Weltje, G.J., Troelstra, S.R., Brummer, G.J.A., 2012.

956 Temporal offsets between surface temperature, ice-rafting and bottom flow speed proxies

957 in the glacial (MIS 3) northern North Atlantic. Quaternary Science Reviews 48, 43-53.

958 Khan, S.e.a., 2014. Sustained mass loss of the northeast Greenland ice sheet

959 triggered by regional warming. Nat. Clim. Chang.4, 292-299. doi:10.1038/NCLIMATE2161 . 
960 Knudsen, K.-L., Jiang, D., Jansen, E., Eiriksson, J., Heinemeier, J., Seidenkrantz, M.-S.,

961 2003. Environmental changes off North Iceland during the deglaciation and the Holocene:

962 foraminifera, diatoms and stable isotopes. Marine Micropaleontology 953, 1-33.

963 Knudsen, K.L., Jiang, H., Jansen, E., Eiriksson, J., Heinemeier, J., Seidenkrantz, M.S.,

964 2004. Environmental changes off North Iceland during the deglaciation and the Holocene:

965 foraminifera, diatoms and stable isotopes. Marine Micropaleontology 50, 273-305.

966 Kraus, W., 1958. Die hydrographischen Untersuchungen mit "Anton Dohrn" auf dem ost-

967 westgronlandischen Schelf im September-Oktober 1955. Ber. Disch. Wiss. Komm.

968 Meresforsch. 15, 77-104.

969 Kristjansdottir, G.B., Moros, M., Andrews, J.T., Jennings, A.E., 2016 Holocene Mg/Ca,

970 alkenones, and light stable isotope measurements on the outer North Iceland shelf

971 (MD99-2269): A comparison of proxy data The Holocene, 1-11.

972 Kuijpers, A., Troelstra, S.R., Prins, M.A., Linthout, K., Akhmetzhanov, A., Bouryak, S.,

973 Bachmann, M.F., Lassen, S., Rasmussen, S., Jensen, J.B., 2003. Late Quaternary

974 sedimentary processes and ocean circulation changes at the Southeast Greenland margin.

975 Marine Geology 195, 109-129.

976 Labeyrie, L., Jansen, E., Cortijo, E., 2003. Les rapports de campagnes a la mer

977 MD114/IMAGES V. Institut Polaire Francais Paul-Emile Victor, Brest.

978 Lambeck, K., Rouby, H., Purcell, A., Sun, Y., Sambridge, M., 2014. Sea level and global

979 ice volumes from the Last Glacial Maximum to the Holocene. Proceedings of the

980 National Academy of Sciences of the United States of America 111, 15296-15303.

981 Larsen, B., 1983. Geology of the Greenland-Iceland Ridge in the Denmark Strait, in: Bott,

982 M.H.P., Saxov, S., Talwani, M., Thiede, J. (Eds.), Structure and Development of the

983 Greenland-Scotland Ridge. Plenum Publishing Corp., London, pp. 425-444.

984 Larsen, M., Hamberg, L., Olaussen, S., Norgaard-Pedersen, N., Stemmerik, L., 1999.

985 Basin evolution in Southern East Greenland: An outcrop analog for Cretaceous-

986 Paleogene basins on the North Alantic volcanic margins. AAPG Bulletin 83, 1236-1261.

987 Lecavalier, B.S., Milne, G.A., Simpson, M.J.R., Wake, L., Huybrechts, P., Tarasov, L.,

988 Kjeldsen, K.K., Funder, S., Long, A.J., Woodroffe, S., Dyke, A.S., Larsen, N.K., 2014. A

989 model of Greenland ice sheet deglaciation constrained by observations of relative sea

990 level and ice extent. Quaternary Science Reviews 102, 54-84. 
991 Lind, E.W., Lilja, C., Wastegard, S., Pearce, N.J.G., 2016. Revisiting the Borrobol 992 Tephra. Boreas.

993 Lohne, O.S., Mangerud, J., Birks, H.H., 2013. Precise C-14 ages of the Vedde and 994 Saksunarvatn ashes and the Younger Dryas boundaries from western Norway and their 995 comparison with the Greenland Ice Core (GICC05) chronology. Journal of Quaternary 996 Science 28, 490-500.

997 Marcott, S.A., Bauska, T.K., Buizert, C., Steig, E.J., Rosen, J.L., Cuffey, K.M., Fudge, T.J., 998 Severinghaus, J.P., Ahn, J., Kalk, M.L., McConnell, J.R., Sowers, T., Taylor, K.C., White, 999 J.W.C., Brook, E.J., 2014. Centennial-scale changes in the global carbon cycle during the last 1000 deglaciation. Nature 514, 616-+.

1001 Manley, W.F., Jennings, A.E., 1996. Radiocarbon Date List VIII: Eastern Canadian 1002 Arctic, Labrador, Northern Quebec, East Greenland Shelf, Iceland Shelf, and Antarctica. 1003 INSTAAR, University of Colorado, p. 163 pp.

1004 Massé, G., Belt, S.T., Crosta, X., Schmidt, S., Snape, I., Thomas, D.N. and Rowland, S.J. 1005 (2011) Highly branched isoprenoids as proxies for variable sea ice conditions in the 1006 Southern Ocean. Antarctic Science 23, 487-498

1007 Mienert, J., 1990. Forschungsschiff POSEIDON. Reise Nr. 175/1 9/10-21/10 1990. 1008 GEOMAR, Kiel.

1009 Mienert, J., Andrews, J.T., Milliman, J.D., 1992. The East Greenland Continental Margin

$1010(65 \mathrm{~N})$ since the last deglaciation: Changes in sea floor properties and ocean circulation. 1011 Marine Geology 106, 217-238.

1012 Minansy, B., 2010. Fuzzy k means extragrades, performance measures \& fuzzy linear 1013 discriminant analysis. The University of Sydney, Australia, p. 28 pp.

1014 Minasny, B., McBratney, A.B., 2002. FuzMe version 3.0. Australian Center for Precision 1015 Agriculture, Universityof Sydney, Australia.

1016 .Moros, M., Andrews, J.T., Eberl, D.D., Jansen, E., 2006. The Holocene history of drift 1017 ice in the northern North Atlantic: Evidence for different spatial and temporal modes.

1018 Palaeoceanography 21, 1 of 10. doi:10.1029/2005PA001214.

1019 Mortensen, A.K., Biglier, M., Gronvold, K., Steffensen, J.P., Johnsen, S.J., 2005. Volcanic 1020 ash layers from the last Glacial Termination in the NGRIP ice core. Journal of 1021 Quaternary Science 20, 209-220 
1022 Müller, J., Stein, R., 2014. High-resolution record of late glacial sea ice changes in Fram

1023 Strait corroborates ice-ocean interactions during abrupt climate shifts. Earth and

1024 Planetary Science Letters 403, 446-455.

1025 Norddahl, H., 1990. Late Weiechelian and early Holocene deglaciation history of Iceland. Jökull

$102640,27-50$

1027 Norðdahl, H., Ingolfsson, O., 2015. Collapse of the Icelandic ice sheet controlled by sea-

1028 level rise? Arktos, pp 1-18.

1029 O Cofaigh, C., Dowdeswell, J.A., Evans, J., Kenyon, N.H., Taylor, J., Mienert, A., Wilken, M., 1030 2004. Timing and significance of glacially influenced mass-wasting in the submarine channels of

1031 the Greenland Basin. Marine Geology 207, 39-54.

1032 Ogilvie, A.E.J., 1992. Documentary evidence for changes in the climate of Iceland, A.D.

10331500 to 1800, in: Bradley, R.S., Jones, P.D. (Eds.), Climate since A.D. 1500. Routledge,

1034 London, pp. 92-117.

1035 Ogilvie, A.E.J., Jonsdottir, I., 2000. Sea ice, climate, amd Icelandic fisheries in the

1036 eighteenth and nineteenth centuries. Arctic 53, 383-394.

1037 Olafsdottir, S., 2004. Currents and climate on the northwest shelf of Iceland during the

1038 deglaciation: high-resolution foraminiferal research, Department of Geosciences.

1039 University of Iceland, Reykjavik, p. 117.

1040 Olafsdottir, S., Jennings, A.E., Geirsdottir, A., Andrews, J., Miller, G.H., 2010. Holocene

1041 variability of the North Atlantic Irminger current on the south- and northwest shelf of

1042 Iceland. Marine Micropaleontology 77, 101-118.

1043 Patton, H., Hubbard, A., Bradwell, T., Schomacker, A., 2017. The configuration,

1044 sensitivity and rapid retreat of the Late Weischelian Icelandic Ice Sheet. Earth-

1045 Science Reviews 166, 223-245.

1046 Petursson, H.G., Norddahl, H., Ingolfsson, O., 2015. Late Weichselian history of

1047 relative sea level changes in iceland during a collapse and subsequent retreat of

1048 marine based ice sheet. Cuadernos De Investigacion Geografica 41, 261-277.

1049 Peltier, W.R., Argus, D.F., Drummond, R., 2015. Space geodesy constrains ice age

1050 terminal deglaciation: The global ICE-6G_C (VM5a) model. Journal of Geophysical

1051 Research-Solid Earth 120, 450-487. 
1052 Perner, K., Jennings, A.E., Moros, M., Andrews, J.T., Wacker, L., 2016. Millennial scale 1053 mid to late Holocene oscillation of the East Greenland and Irminger Current on the south1054 eastern Greenland shelf Journal of Quaternary Science.

1055 Praetorius, S.K., Mix, A.C., 2014. Synchronization of North Pacific and Greenland 1056 climates preceded abrupt deglacial warming. Science 345, 444-448.

1057 Praetorious, S.K., Mix, A.C., 2016. Did synchronized ocean warming in the North Pacific 1058 and North Atlantic trigger a deglacial tipping point in the Northern Hemiepshere? Past 1059 Global Change 24, 10-11.

1060 Principato, S.M., 2003. The late Quaternary history of eastern Vestfirdir, NW Iceland, 1061 Geological Sciences. University of Colorado, Boulder, p. 258.

1062 Principato, S.M., Geirsdottir, A., Johannsdottir, G.E., Andrews, J.T., 2006. Late

1063 Quaternary glacial and deglacial history of eastern Vestfirdir, Iceland using cosmogenic 1064 isotope $(36 \mathrm{Cl})$ exposure ages and marine cores. Journal of Quaternary Science 21, 2711065286.

1066 Principato, S.M., Moyer, A.N., Hampsch, A.G., Ipsen, H.A., 2016. Using GIS and streamlined 1067 landforms to interpret palaeo-ice flow in northern Iceland. Boreas 45, 470-482.

1068 Prins, M.A., Bouwer, L.M., Beets, C.J., Troelstra, S.R., Weltje, G.J., Kruk, R.W., 1069 Kruijpers, A., Vroon, P.Z., 2002. Ocean circulation and iceberg discharge in the glacial 1070 North Atlantic: Inferences from unmixing of sediment sizes. Geology 30, 555-558.

1071 Quillmann, U., 2006. Holocene environmental variability in Isafjardardjup and its 1072 tributary fjords, NW Iceland, Geological Sciences. University of Colorado, Boulder, p. 1073280.

1074 Quillmann, U., Andrews, J.T., Jennings, A.E., 2009. Radiocarbon Date List XI: East 1075 Greenland shelf, West Greenland Shelf, Labrador Sea. Baffin Island shelf, Baffin Bay, 1076 Nares Strait, and Southwest to Northwest Icelandic shelf. Occasional Paper No. 59, 1077 INSTAAR, University of Colorado, Boulder, Boulder, p. 68.

1078 Quillmann, U., Jennings, A.E., Andrews, J.T., 2010. Reconstructing Holocene 1079 paleocliumate and paleoceanography in Isafjaradrdjup, Northwest Iceland, from two fjord 1080 cores overprinted by relative sea level and local hydrographic changes. Journal of 1081 Quaternary Science 25, 1144-1159. 
1082 Rasmussen, S.O., Bigler, M., Blockley, S.P., Blunier, T., Buchardt, S.L., Clausen, H.B.,

1083 Cvijanovic, I., Dahl-Jensen, D., Johnsen, S.J., Fischer, H., Gkinis, V., Guillevic, M.,

1084 Hoek, W.Z., Lowe, J.J., Pedro, J.B., Popp, T., Seierstad, I.K., Steffensen, J.P., Svensson,

1085 A.M., Vallelonga, P., Vinther, B.M., Walker, M.J.C., Wheatley, J.J., Winstrup, M., 2014.

1086 A stratigraphic framework for abrupt climatic changes during the Last Glacial period

1087 based on three synchronized Greenland ice-core records: refining and extending the

1088 INTIMATE event stratigraphy. Quaternary Science Reviews 106, 14-28.

1089 Roy, K., Peltier, W.R., 2015. Glacial isostatic adjustment, relative sea level history and

1090 mantle viscosity: reconciling relative sea level model predictions for the US East coast

1091 with geological constraints. Geophysical Journal International 201, 1156-1181.

1092 Rytter, F., Knudsen, K.-L., Seidenkrantz, M.-S., Eiriksson, J., 2002. Modern distribution

1093 on benthic foraminifera on the North Icelandic shelf and slope. Journal of Foraminferal

1094 Research 32, 217-244.

1095 Sarna-Wojcicki, A.M., Bowman, H.R., Meyer, C.E., Russell, P.C., Woodward, M.J., G., M.,

1096 Rowe, J.J.J., Baedecker, P.A., Asaro, F., Michael, H., 1984. Chemical analyses, correlations, and

1097 ages of Upper Pliocene and Pleistocene as layers of East-Central and southern California. United

1098 States Geological Survey, Washington, DC, p. 33 pp.

1099 Sarnthein, M., Balmer, S., Grootes, P.M., Mudelsee, M., 2015. Planktic and benthic c-14

1100 reservoir ages for three ocean basins, calibrated by a suite of c-14 plateaus in the glacial-

1101 to-deglacial atmospheric c-14 record. Radiocarbon 57, 129-151.

1102 Seale, A., Christoffersen, P., Mugford, R.I., O'Leary, M., 2011. Ocean forcing of the

1103 Greenland Ice Sheet: Calving fronts and patterns of retreat identified by automatic

1104 satellite monitoring of eastern outlet glaciers. Journal of Geophysical Research-Earth

1105 Surface 116,1 of 16.

1106 Seidov, D., Baranova, O.K., Boyer, T., Cross, S., Mishonov, A., Parsons, A.R., 2016. Northwest

1107 Atlantic regional ocean climatology. NOAA Atlas NESDIS80, in: A.V.Mishonov (Ed.), 56pp.

1108 Sinclair, G., Carlson, A.E., Mix, A.C., Lecavalier, B.S., Milne, G., Mathias, A., Buizert,

1109 C., DeConto, R., 2016. Diachronous retreat of the Greenland ice sheet during the last

1110 deglaciation. Quaternary Science Reviews 145, 243-258.

1111 Smith, L.M., Andrews, J.T., Castaneda, I.S., Kristjansdottir, G.B., Jennings, A.E.,

1112 Sveinbjjronsdottir, A.E., 2005. Temperature reconstructions for SW amd N Iceland 
1113 waters over the last 10,000 cal yr B.P. based on d180 records from planktic and benthic 1114 Foraminifera. Quaternary Science Reviews 24, 1723-1740.

1115 Smith, L.M., Licht, K.J., 2000. Radiocarbon Date List IX: Antarctica, Arctic Ocean, and 1116 the Northern North Atlantic. INSTAAR Occasional paper No. 54, University of Colorado, 1117138 pp, Boulder, CO, p. 138.

1118 Stein, A.B., 1996. Seismic stratigraphy and seafloor morphology of the Langerlussuaq

1119 region, East Greenland: Evidence for glaciations to the Continental Shelf break during

1120 the late Weischelian Age and earlier, Geological Sciences. University of Colorado,

1121 Boulder, p. 293 pp.

1122 Stein, R., Fahl, K., Schade, I., Manerung, A., Wassmuth, S., Niessen, F., Nam, S., 2017.

1123 Holocene variability in sea ice cover, primary production, and Pacific-Water inflow and

1124 climate change in the Chukchi and East Siberian Seas (Arctic Ocean). Journal of

1125 Quaternary Science 32, 362-379.

1126 Stern, J.V., Lisiecki, L.E., 2013. North Atlantic circulation and reservoir age changes over the 1127 past 41,000years. Geophysical Research Letters 40, 3693-3697.

1128 Syvitski, J.P., Jennings, A.E., Andrews, J.T., 1999. High-Resolution Seismic Evidence

1129 for Multiple Glaciation across the Southwest Iceland Shelf. Arctic and Alpine Research $113031,50-57$.

1131 Syvitski, J.P.M., Andrews, J.T., Dowdeswell, J.A., 1996. Sediment deposition in an 1132 iceberg-dominated Glacimarine Environment, East Greenland: Basin Fill Implications. 1133 Global and Planetary Change 12, 251-270.

1134 Syvitski, J.P.M., Stein, A., Andrews, J.T., Milliman, J.D., 2001. Icebergs and seafloor of 1135 the East Greenland (Kangerlussuaq) continental margin. Arctic, Antarctic and Alpine 1136 Research 33, 52-61.

1137 Tanner, W.F., 1965. Cause and Development of an Ice Age. The Journal of Geology 73.

1138 Thiagarajan, N., Subhas, A.V., Southon, J.R., Eiler, J.M., Adkins, J.F., 2014. Abrupt pre-

1139 Bolling-Allerod warming and circulation changes in the deep ocean. Nature 511, 75$1140 \quad \mathrm{U} 409$.

1141 Tarasov, L., Peltier, W.R., 2002. Greenland glacial history and local geodynamic 1142 consequences. Geophysical Journal International 150, 198-229. 
1143 Thordardottir, T., 1984. Primary Production North of Iceland in relation to Water Masses 1144 in May-June 1970-1980. Conference for the Exploration of the Sea, C.M. 1984/L20, 1-17.

1145 Thordardottir, T., 1986. Timing and Duration of Spring Blooming South and Southwest 1146 of Iceland. NATO ASI Series G-7, 345-360.

1147 Thornalley, D.J.R., Barker, S., Broecker, W.S., Elderfield, H., McCave, I.N., 2011. The

1148 Deglacial Evolution of North Atlantic Deep Convection. Science 331, 202-205.

1149 Thornalley, D.J.R., Bauch, H.A., Gebbie, G., Guo, W., Ziegler, M., Bernasconi, S.M., 1150 Barker, S., Skinner, L.C., Yu, J., 2015. A warm and poorly ventilated deep Arctic

1151 Mediterranean during the last glacial period. Science 349, 706-710.

1152 Thors, K., 1974. Sediments of the Vestfirdir Shelf, NW Iceland. Univ. of Manchester.

1153 Turney, C.S.M., Fogwill, C.J., Lenton, T.M., Jones, R.T., 2016. Tipping Points: Lessons

1154 from the Past for the Future. Past Global Change 24, 3.

1155 van Kreveld, S., Sarthein, M., Erlenkeuser, H., Grootes, P., Jung, S., Nadeau, M.J., 1156 Pflaumann, U., Voelker, A., 2000. Potential links between surging ice sheets, circulation 1157 changes, and the Dansgaard-Oeschger cycles in the Irminger Sea, 60-18 ka.

1158 Paleoceanography 15, 425-442.

1159 Vasskog, K., Langebroek, P.M., Andrews, J.T., Nilsen, J.E.O., Nesje, A., 2015. The 1160 Greenland Ice Sheet during the last glacial cycle: Current ice loss and contribution to sea1161 level rise from a palaeoclimatic perspective. Earth-Science Reviews 150, 45-67.

1162 Vinther, B.M., Clausen, H.B., Fisher, D.A., Koerner, R.M., Johnsen, S.J., Andersen, K.K., 1163 Dahl-Jensen, D., Rasmussen, S.O., Steffensen, J.P., Svensson, A.M., 2008.

1164 Synchronizing ice cores from the Renland and Agassiz ice caps to the Greenland ice core 1165 chronology. Journal of Geophysical Research-Atmospheres 113. 1 of 10.

1166 10.1029/2007JD009143.

1167 Voelker, A.H.L., Haflidason, H., 2015. Refining the Icelandic tephrachronology of the 1168 last glacial period - The deep-sea core P52644 record from the southern Greenland Sea. 1169 Global and Planetary Change 131, 35-62.

1170 Weltje, G.J., Prins, M.A., 2003. Muddled or mixed? Inferring palaeoclimate from size 1171 distributions of deep-sea clastics. Sedimentary Geology 162, 39-62.

1172 Weltje, G.J., Prins, M.A., 2007. Genetically meaningful decomposition of grain-size 1173 distributions. Sedimentary Geology 202, 409-424. 
1174 Xiao, X., Zhao, M., Knudsen, K.L., Sha, L., Eiríksson, J., Gudmundsdóttir, E., Jiang, H., 1175 Guo, Z., 2017. Deglacial and Holocene sea-ice variability northof Iceland and 1176 response to ocean circulation changes. Earth and Planetary Science Letters 472, 14117724.

1178

1179

1180

1181

1182

1183

1184

1185

1186

1187

1188

1189

1190

1191

1192

1193

1194

1195

1196

1197

1198 
Figure 1A: Map of the Denmark Strait area showing the primary cores (solid squares), cores noted in the text and providing information (filled stars; Suppl.Table 1). Dotted blue line = average position of the sea ice edge (15\% coverage) April AD 1870-1920 (Divine and Dick, 2006). KT = Kangerlussuaq Trough, $\mathrm{H}=$ Húnaflói, the Djúpáll Trough is located at core MD99-2264. Surface Atlantic Currents: Irminger Current = IC, North Iceland Irminger Current (NIIC); cold surface Arctic/Polar Currents: East Greenland Current = EC, East Iceland Current = EIC. B) Map of basal uncorrected 14C dates and whether the core penetrated a basal diamicton (Dmm). Black squares show the two cores with stable isotope records across the glacial/deglacial transition. C) The calibrated $14 \mathrm{C}$ dates with values based on a $\Delta \mathrm{R}$ of 0 versus the sliding scale $\Delta \mathrm{R}$ estimates (Table 2). The number in brackets along Kangerlussuaq Fjord (11.8 cal ka BP) is the average cosmogenic date (Dyke et al., 2014). 


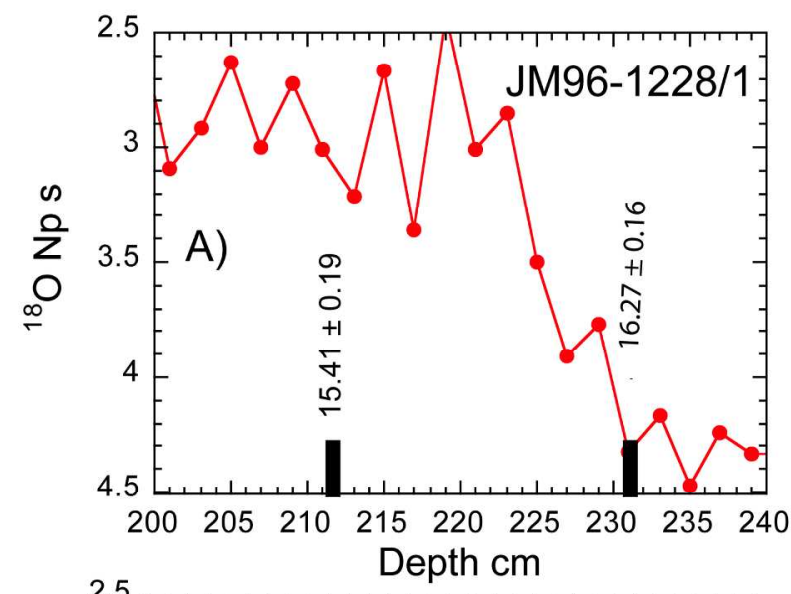

\section{North}

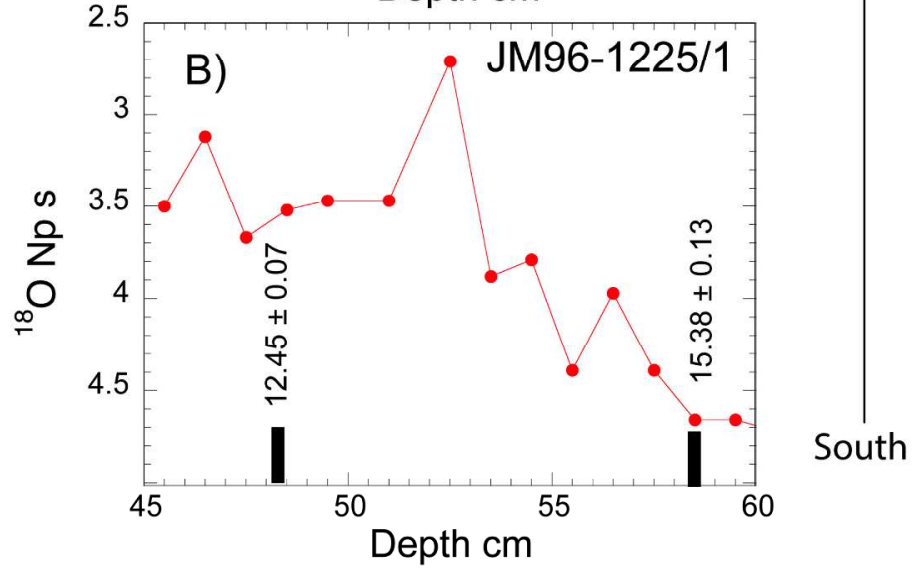

Figure 2: Neogloboquadrina pachyderma s $\delta 180$ records from north and south of Denmark Strait (Hagen, 1999 ) illustrating the transition from glacial to interstadial values, and the differences in the radiocarbon dates that we assume is associated with regional variations in the ocean reservoir correction (see text).

$258 \times 329 \mathrm{~mm}(300 \times 300 \mathrm{DPI})$ 
Figure 3: Analysis of the grain-size spectra $(n=191)$. A) Plot of the 3 performance indictors in FuzMe

(Minansy, 2010; Minasny and McBratney, 2002) (MPE= modified partition entropy, FPI = fuzziness performance indicator, $\mathrm{S}=$ Compactness and separation validity function) indicating the optimal solution of 4 Grain-size mode (GSM) clusters; B) Probability plot of the Confusion Index (CI) ( 0 = certainty of cluster membership, 1 = equal mixture of the 3 grain-size modes C) Plot of the average grain-size spectra for the 3 GSMs; D) Plot of the mean grain-size $(\mu \mathrm{m})$ and sorting; E) Plot of the percentages of medium sand versus medium silt; and F) Plot of aspects of the shape of the grain-size spectra, Skewness versus Kurtosis (Folk and Ward, 1957; Blott and Pye, 2001).

$226 \times 214 \mathrm{~mm}(300 \times 300 \mathrm{DPI})$ 
Fig. 4 
A
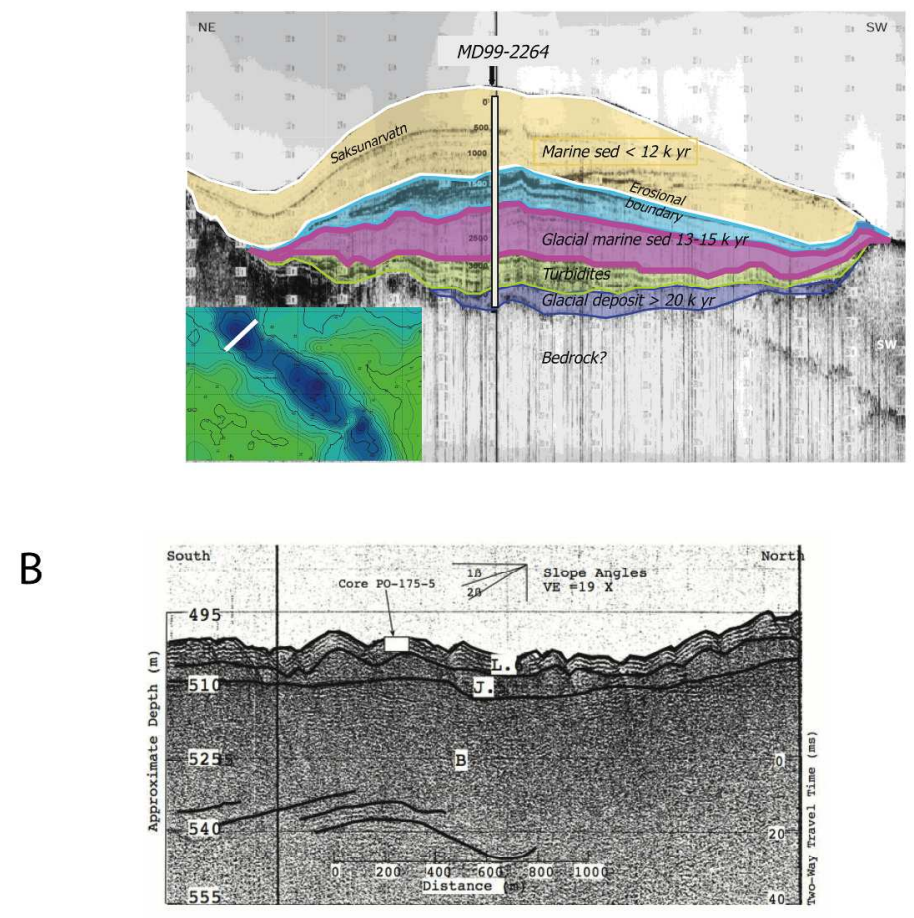

C

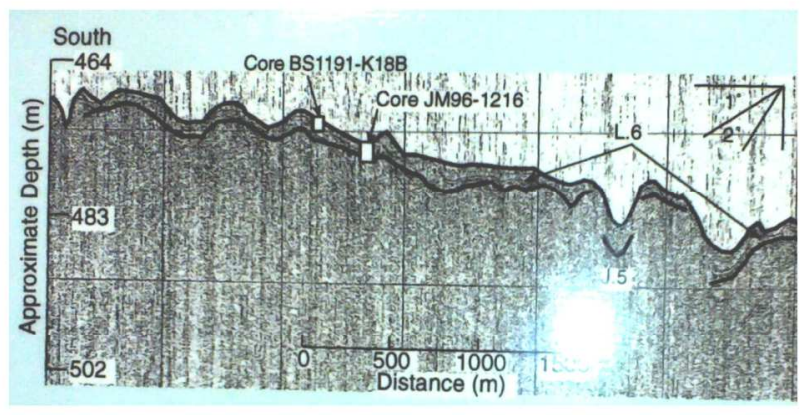

Fig. 5

$279 \times 361 \mathrm{~mm}(300 \times 300$ DPI $)$ 

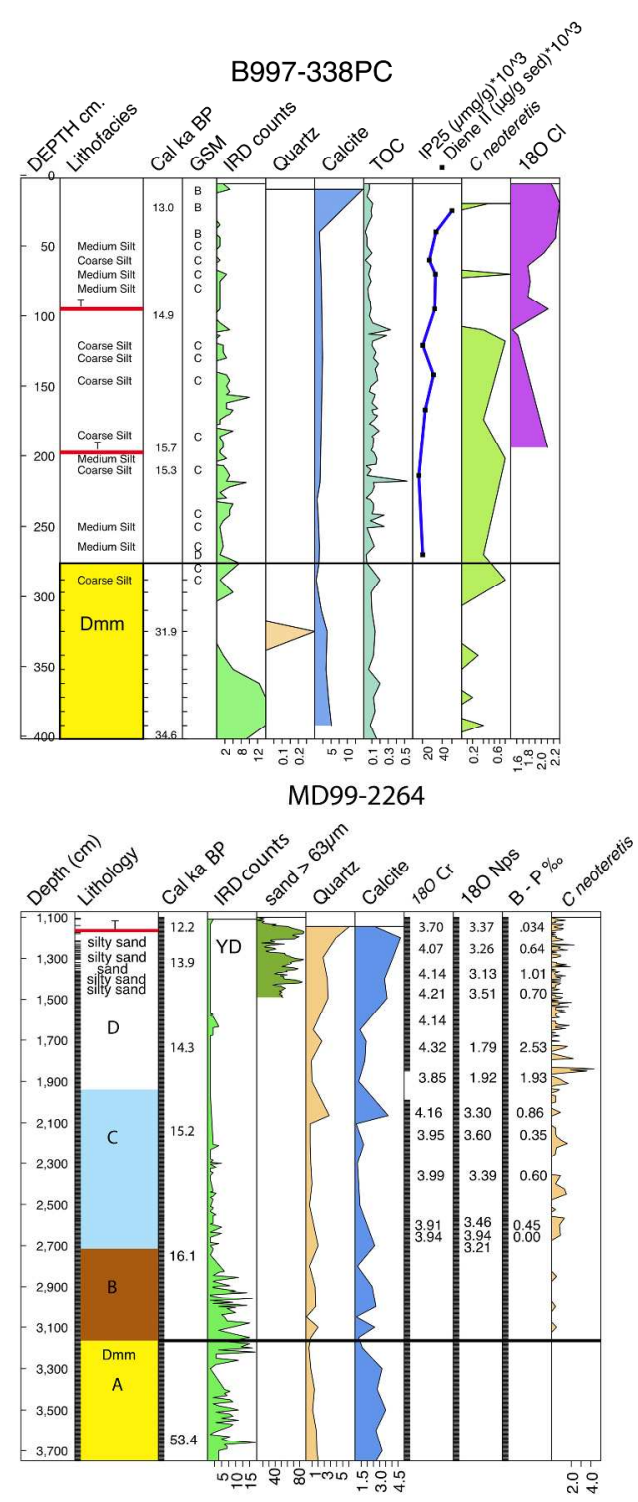

Fig. 6

$279 \times 361 \mathrm{~mm}(300 \times 300$ DPI) 


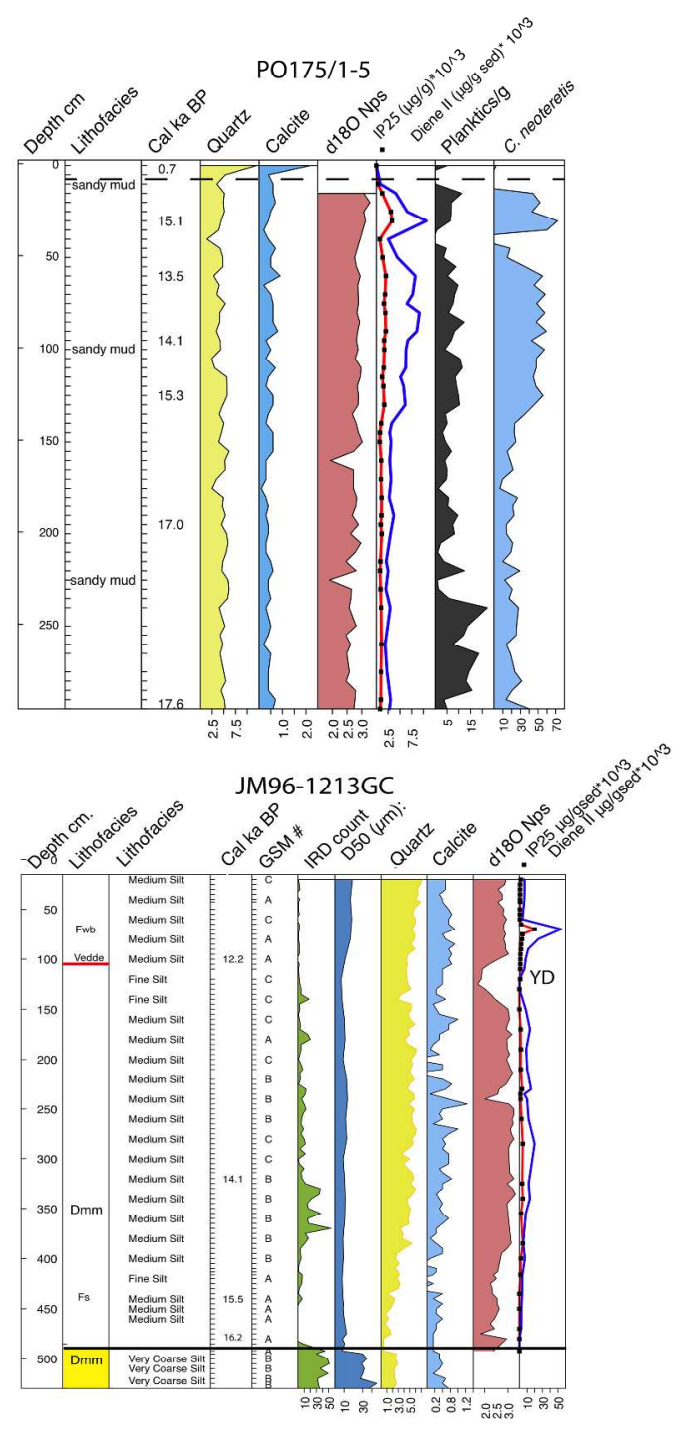

Fig. 7

$279 \times 361 \mathrm{~mm}(300 \times 300 \mathrm{DPI})$ 


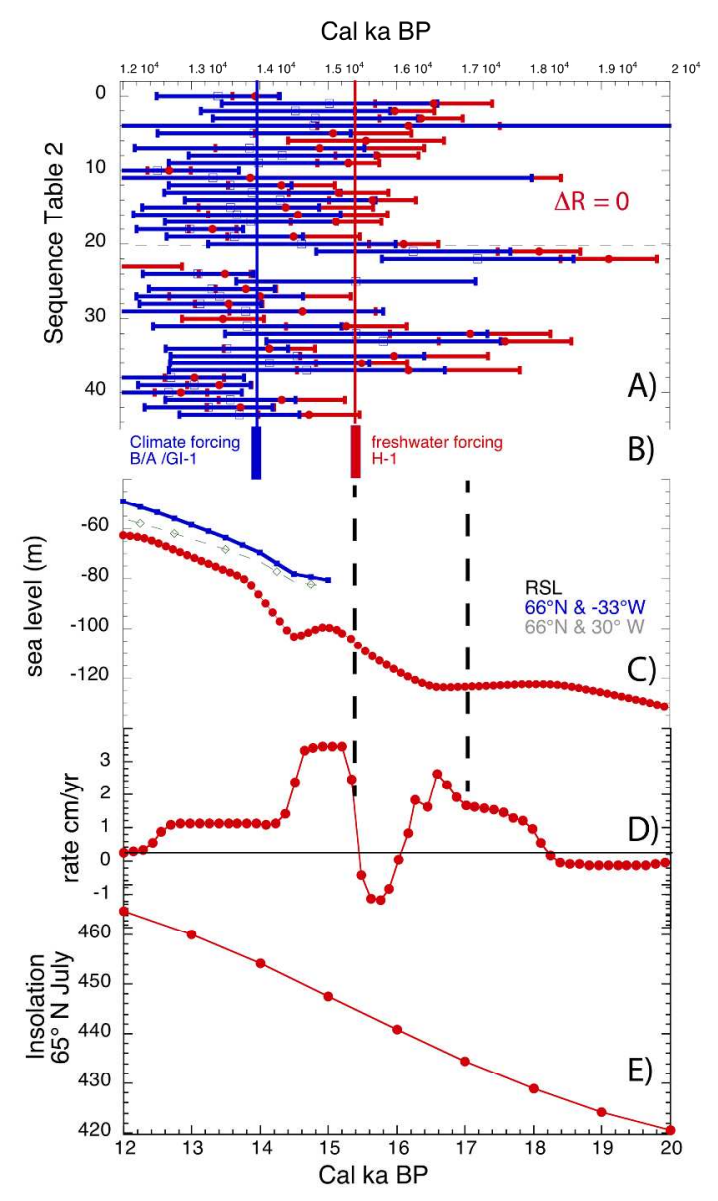

Figure 8: Global and regional parameters operating in the period between 12 and $17 \mathrm{cal}$ ka BP. A) Plot of median calibrated ages and the $95 \%$ confidence interval for sites discussed in this paper (Fig. 1, see Table 2) using $\Delta R=0$ (red) and $\Delta R \leq 1000 \mathrm{yr}$ (blue). The vertical solid blue and red lines represent the median ages for the basal dates for the two $\Delta R$ options; C) Eustatic sea level (Lambeck et al., 2014) and estimates of relative sea level change (RSL) at specific latitudes and longitudes (Peltier, person. commun. 2016). D) Rate of change of global sea level (C); and E) July Insolation at $65^{\circ} \mathrm{N}$ (Berger and Loutre, 1991);

\section{$279 \times 361 \mathrm{~mm}(300 \times 300 \mathrm{DPI})$}



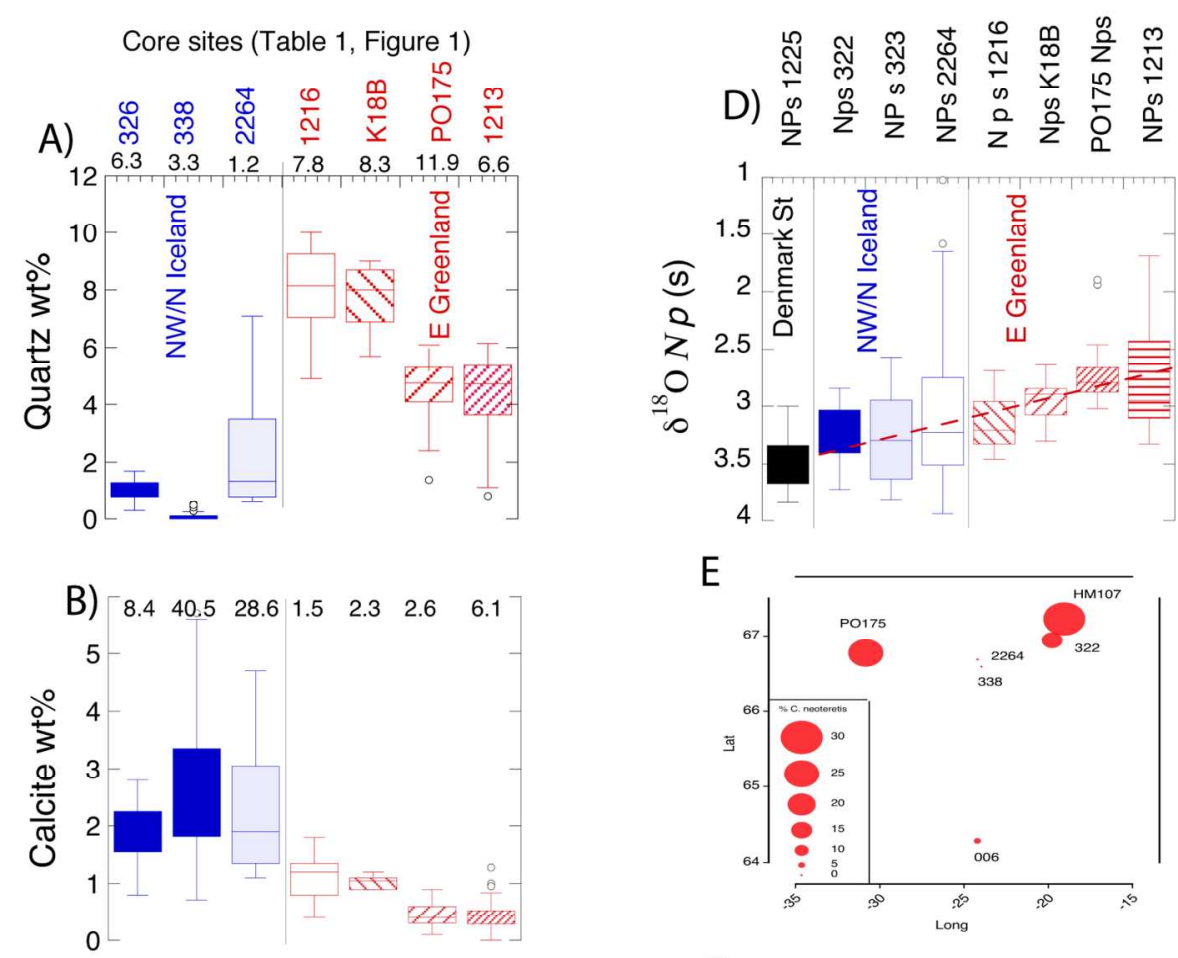

E
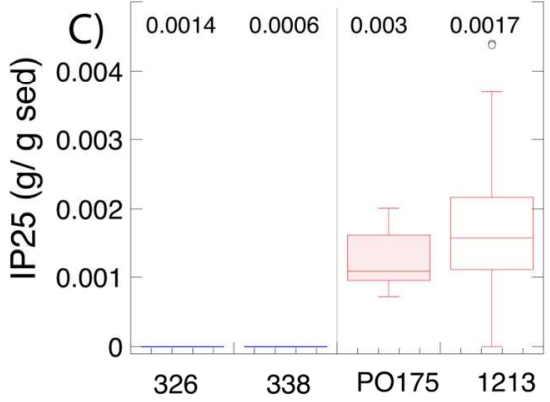

Figure 9: Box plots of surface \& near-surface environment proxies across Denmark Strait (east to west) between 12 to 15 cal ka BP--- -numbers give the wt\% of modern samples showing: A) Weight \% quartz; B) Weight \% calcite; and C) IP25; D) $\delta 180$ for the near-surface polar planktonic foraminifera Neogloboquadrina pachyderma; E) Map of the \% of C. neoteretis for the deglacial interval > 12 cal ka BP; F) Diene II.

$178 \times 207 \mathrm{~mm}(300 \times 300 \mathrm{DPI})$

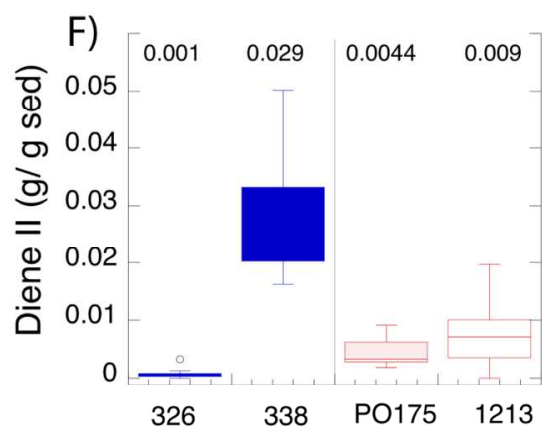



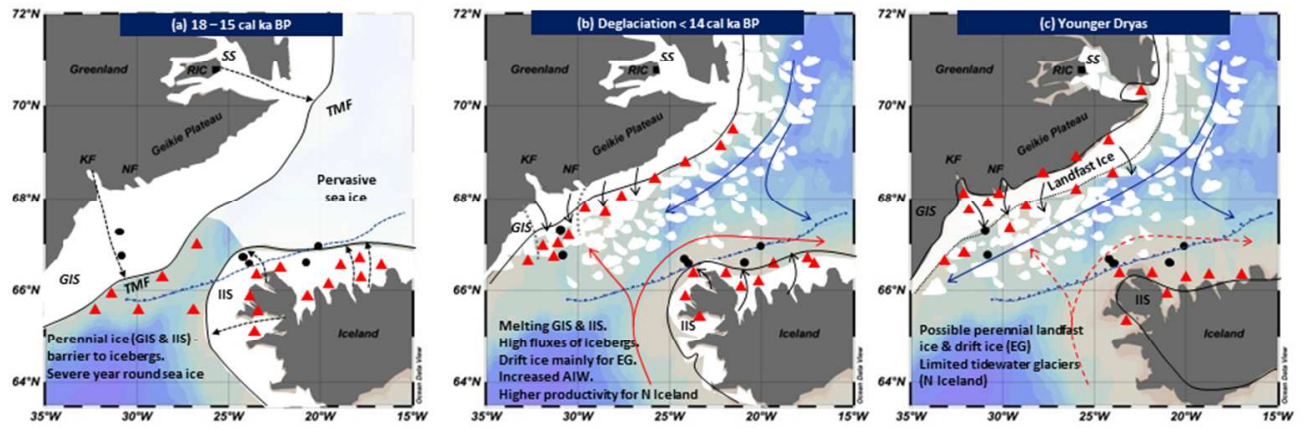

Figure 10: Simplified scenarios of conditions in Denmark Strait at the end of MIS2 and during the initial period of deglaciation. Red triangles represent icebergs and the white patches represent sea ice. Black dots refer to the core locations as listed in Table 1. Red arrows represent warm surface (Atlantic Water) currents and the dark blue represents the export of cold Polar Water. A) Ice Sheet extent during the LGM; B) conditions during deglaciation, and C) Conditions at the YD interval.

$254 \times 190 \mathrm{~mm}(96 \times 96$ DPI $)$ 


\section{Supplemental Material}

\section{Methods}

4

5 Coarse ice-rafted sediment $>\mathbf{2} \mathbf{~ m m}$ : The number of clasts $>2 \mathrm{~mm}$ were counted in 2 -

$6 \mathrm{~cm}$ vertical increments on X-radiographs of the split cores (Andrews et al., 1997;

7 Geirsdottir et al., 2002). These counts are used as the most definitive evidence of ice-

8 rafting debris (IRD) associated with deposition from icebergs (Andrews, 2000)(Andrews, $92000)$.

10 Grain-size: Lithofacies were based on visual inspection and examination of X-

11 radiographs on split cores. Grain-size data were obtained on 162 samples from cores

12 B997-322, -323, -326, -328 and JM96-1213 with boundaries between 2000 and $2 \mu \mathrm{m}$.

13 The samples were processed on the Malvern long-bed laser system after treatment with

14 hydrogen peroxide to remove any organics. Samples were not decalcified as detrital

15 carbonate can be an important signal of the export of sediment from or from the extensive

16 limestone outcrops in N Greenland and the Canadian Arctic Archipelago. Furthermore,

17 decalcification of samples from MD99-2269 (Andrews et all, 2003) resulted in little

18 change in grain-size properties. Grain-size statistics were obtained using Gradistat (Blott

19 and Pye, 2001)(Blott and Pye, 2001). Rather than just report variations in parameters,

20 such as mean grain-size, we sought to more rigorously characterize the grain-size

21 distributions (Weltje and Prins, 2003; Weltje and Prins, 2007).(Weltje and Prins, 2003;

22 Weltje and Prins, 2007) 
X-ray diffraction of $<\mathbf{2} \mathbf{~ m m}$ sediment fraction: Quantitative X-ray diffraction

24 (qXRD) analysis of the $<2 \mathrm{~mm}$ sediment fraction was undertaken using the method

25 outlined by Eberl (Eberl, 2003)(Eberl, 2003) is which 10\% by weight of $\mathrm{ZnO}$ is added to

26 the sample, milled for 5 minutes in a McCrone mill, dried, and then loaded into a

27 Siemens D5000 X-ray diffractometer. Each sample runs for 100 minutes with scanning

28 taking place in 0.02 2-theta steps between 5 and $65^{\circ} 2$-theta, and measured intensities

29 recorded every 2 secs. The data are then downloaded and weight $\%$ of minerals estimated

30 using the Excel macro program Rockjock v6 (Eberl, 2003). qXRD data from the area

31 have been reported previously (Andrews, 2008; Andrews and Eberl, 2007). The QXRD

32 data have been used in a sediment umixing model (Andrews and Eberl, 2012) to better

33 understand the varying contributions from possible bedrock source areas (Andrews et al.,

34 2015).

35 Light Stable Isotopes: $\delta^{18} \mathrm{O}$ and $\delta^{13} \mathrm{C}$ data have been obtained on both benthic

36 and planktonic foraminifera for our sites, but at varying levels of resolution. Details on

37 the processing of the samples are given in Olafsdottir (Olafsdottir, 2004). Data were

38 obtained on the dominant polar planktonic foraminifera Neogloboquadrina pachyderma $\mathrm{s}$

39 and on several species of benthic foraminifera. We compare our data with $\delta^{18} \mathrm{O}$ values o

40 Neogloboquadrina pachyderma s from cores in the area of Denmark Strait, namely

41 JM96-1225, -1228 (Hagen, 1999b; Hagen and Hald, 2002) and MD99-2323 (Dunhill,

42 2005) (Fig. 1). There is also a considerable body of information on both modern

43 (surface) and Holocene $\delta^{18} \mathrm{O}$ ratios on both planktonic and benthic foraminifera from

44 both shelves (Castaneda et al., 2004; Jennings et al., 2011; Knudsen et al., 2004;

45 Kristjansdottir et al., 2016 ; Smith et al., 2005). 
Foraminfera assemblages: Details of the sample processing for foraminifera

47 are given in Olafsdottir (Olafsdottir, 2004) and Jennings et al (Jennings et al., 2004).

48 Interpretations are based on the analysis of the occurrence of species in seafloor

49 sediments collected in the 1990s (Jennings and Helgadottir, 1994; Jennings et al., 2004;

$50 \quad$ Rytter et al., 2002).

51 Biomarkers: Biomarker analyses $\left(\mathrm{IP}_{25}\right.$ and $\left.\mathrm{C}_{25: 2}\right)$ were performed on 107 samples

52 from cores B997-326 $(\mathrm{n}=21),-338(\mathrm{n}=8)$, JM96-1213 $(\mathrm{n}=43)$ and 175PO/1-5 $(\mathrm{n}=$

53 35), using methods described previously (Belt et al., 2012; Belt et al., 2013). Briefly, two

54 internal standards, 7-hexylnonadecane and 9-octylheptadec-8-ene (each $0.10 \mu \mathrm{g}$ ) were

55 added to freeze-dried sediment samples (ca. $3 \mathrm{~g}$ ) to permit quantification of $\mathrm{IP}_{25}$ and

$56 \mathrm{C}_{25: 2 .}$. Samples were then extracted using dichloromethane/methanol $(3 \times 3 \mathrm{~mL} ; 2: 1 \mathrm{v} / \mathrm{v}$;

57 ultrasonication; $15 \mathrm{~min}$ ). Dried total organic extracts were then partially purified using

58 column chromatography (silica; hexane; $6 \mathrm{~mL}$ ) and further fractionated into saturated and

59 unsaturated components using silver ion solid-phase extraction (SPE) material (100 mg;

60 Supelco discovery ${ }^{\circledR}$ Ag-Ion). Saturated and unsaturated (including $\mathrm{IP}_{25}$ and $\mathrm{C}_{25: 2}$ )

61 hydrocarbons were with hexane $(1 \mathrm{~mL})$ and acetone $(2 \mathrm{~mL})$, respectively. Analysis of

62 purified fractions was carried out using gas chromatography-mass spectrometry (GC-

63 MS) as described previously (Belt et al., 2012). Mass spectrometric analysis was mainly

64 carried out in single-ion monitoring (SIM) mode. $\mathrm{IP}_{25}$ and $\mathrm{C}_{25: 2}$ were identified on the

65 basis of their characteristic GC retention indices and mass spectra obtained from

66 standards, while quantification was achieved by comparison of mass spectral responses of

67 selected ions $\left(\mathrm{IP}_{25}: \mathrm{m} / \mathrm{z} 350 ; \mathrm{C}_{25: 2}: \mathrm{m} / \mathrm{z} 348\right)$ with that of the internal standard $(\mathrm{m} / \mathrm{z} 350)$

68 and normalized according to relative response factors and sediment masses (Belt et al., 
69 2012). Analytical reproducibility was monitored using standard sediment with a known

70 concentration of $\operatorname{IP}_{25}(8 \%, n=8)$.

71 Depth/age radiocarbon models:

72 In sites MD99-2264 and JM96-1213 there are sufficient dates over a reasonable depth

73 span to construct depth/age curves using the two $\Delta \mathrm{R}$ options (Suppl. Table 1). We used

74 the flexible Bayesian program (Bacon) (Blaauw and Christen, 2011) to reconstruct

75 depth/age plots (Suppl. Fig. 1)--- in Figures 6B and 7B these are simplified and only the

76 median ages are plotted. Accumulation rates were high at both sites and both models

77 tended to overestimate the age of sediment at the depth of the Vedde tephra (Suppl. Fig.

78 1) indicating either a change in the prior or a need to change $\Delta \mathrm{R}$. In both cores the rates

79 of accumulation are essentially constant. The variations of age versus depth in PO175/1-

805 (Suppl. Table 1) were such that we have not used an age model in Fig. 7A but the

81 results of the two alternative $\Delta$ Rs are plotted on Suppl. Fig. 1.

82

83 Caption Suppl. Fig. 1: Outputs from the Bayesian calibration program "Bacon"

84 (Blaauw and Christen, 2011, 2016) for MD99-2264, JM96-1213, and PO175/105

85 showing the results with the two different ocean reservoir corrections (see text). The

86 single "best" model is the faint red dashed line. Grey stippled areas are the 95\%

87 confidence limits

88

89

90 Suppl. Table 1:

91 
92 This table lists all the radiocarbon dates used in this paper and shows the number of

93 the date listed on Fig. $8(\operatorname{col} A)$, material dated (B), original data and error (E \& F).

94 Cols $\mathrm{G}$ to $\mathrm{K}$ give the calibrated $95 \%$ age range, median and sigma error with a $\Delta \mathrm{R}=$

950 , and cols $\mathrm{L}$ to $\mathrm{R}$ give the estimated $\Delta \mathrm{R}$, error, $95 \%$ age range, median date and

96 error for calibrations with the variable deltaR (see text).

98 Suppl. Table 2:

99

100 Geochemical analyses for tephras noted in this paper. Data from the University of

101 Colorado's microprobe analysis of the Lipari obsidian standard (Hunt and Hill,

102 1996)is listed first followed by the tephras in B997-338 and -323 and -326

103 (Andrews and Helgadottir, 2003; Andrews et al., 2013).

\section{References cited}

105 Andrews, J.T., 2000. Icebergs and Iceberg Rafted Detritus (IRD) in the North Atlantic:

106 Facts and Assumptions. Oceanography 13, 100-108.

107 Andrews, J.T., 2008. The role of the Iceland Ice Sheet in sediment delivery to the North

108 Atlantic during the late Quaternary: how important was it? Evidence from the area of

109 Denmark Strait. Journal of Quaternary Science 23`, 3-20.

110 Andrews, J.T., Bjork, A.A., Eberl, D.D., Jennings, A.E., Verplanck, E.P., 2015.

111 Significant differences in late Quaternary bedrock erosion and transportation: East versus

112 West Greenland $\sim 70^{\circ} \mathrm{N}$ and the evolution of glacial landscapes. Journal of Quaternary

113 Science 30, 452-463.

114 Andrews, J.T., Eberl, D.D., 2007. Quantitative mineralogy of surface sediments on the

115 Iceland shelf, and application to down-core studies of Holocene ice-rafted sediments.

116 Journal of Sedimentary Research 77, 469-479. 
117 Andrews, J.T., Eberl, D.D., 2012. Determination of sediment provenance by unmixing

118 the mineralogy of source-area sediments: The "SedUnMix" program. Marine Geology

$119291,24-33$.

120 Andrews, J.T., Helgadottir, G., 2003. Late Quaternary ice cap extent and deglaciation of

121 Hunafloaall, NorthWest Iceland: Evidence from marine cores. Arctic, Antarctic, and

122 Alpine Research 35, 218-232.

123 Andrews, J.T., Kristjansdottir, G.B., Eberl, D.D., Jennings, A.E., 2013. A quantitative X-

124 ray diffraction inventory of tephra and volcanic glass inputs into the Holocene marine

125 sediment archives of Iceland: A contribution to V.A.S.T. Polar Research, 1-15.

126 Andrews, J.T., Smith, L.M., Preston, R., Cooper, T., Jennings, A.E., 1997. Spatial and

127 temporal patterns of iceberg rafting (IRD) along the East Greenland margin, ca. $68 \mathrm{~N}$,

128 over the last 14 cal.ka. Journal of Quaternary Science 12, 1-13.

129 Belt, S.T., Brown, T.A., Navarro Rodriguez, A., Cabedo Sanz, P., Tonkin, A., Ingle, R.,

130 2012. A reproducible method for the extraction, identification and quantification of the

131 Arctic sea ice proxy IP25 from marine sediments. Analytical Methods 4, 705-713.

132 Belt, S.T., Brown, T.A., Ringrose, A.E., Cabedo-Sanz, P., Mundy, C.J., Gosselin, M.,

133 Poulin, M., 2013. Quantitative measurement of the sea ice diatom biomarker IP25 and

134 sterols in Arctic sea ice and underlying sediments: Further considerations for palaeo sea

135 ice reconstruction. Organic Geochemistry 62, 33-45.

136 Blaauw, M., Christen, J.A., 2011. Flexible Paleoclimate Age-Depth Models Using an

137 Autoregressive Gamma Process. Bayesian Analysis 6, 457-474.

138 Blaauw, M., Christen, J.A., 2016. Bacon manual- v2.2.ed, 11 pp..

139 Blott, S.J., Pye, K., 2001. GRADISTAT: A grain size distribution and statistics package

140 for the analysis of unconsolidated sediments. Earth Surface Processes and Landforms 26,

$141 \quad 1237-1248$.

142 Eberl, D.D., 2003. User guide to RockJock: A program for determining quantitative

143 mineralogy from X-ray diffraction data. United States Geological Survey, Open File

144 Report 03-78, 40 pp, Washington, DC.

145 Hunt, J.B., Hill, P.G., 1996. An Inter-Laboratory comparison of the electron probe

146 microanalysis of glass geochemistry. Quaternary International 34-36, 229-241. 
147 Jennings, A.E., Helgadottir, 1994. Foraminiferal assemblages from the fjords and shelf of 148 Eastern Greenland. Journal Foraminiferal Research 24, 123-144.

149 Jennings, A.E., Weiner, N.J., Helgadottir, G., Andrews, J.T., 2004. Modern foraminiferal

150 faunas of the Southwest to Northern Iceland shelf: Oceanographic and environmental

151 controls. Journal of Foraminiferal Research 34, 180-207.

152 Olafsdottir, S., 2004. Currents and climate on the northwest shelf of Iceland during the

153 deglaciation: high-resolution foraminiferal research, Department of Geosciences.

154 University of Iceland, Reykjavik, p. 117.

155 Rytter, F., Knudsen, K.-L., Seidenkrantz, M.-S., Eiriksson, J., 2002. Modern distribution

156 on benthic foraminifera on the North Icelandic shelf and slope. Journal of Foraminferal

157 Research 32, 217-244.

158 Weltje, G.J., Prins, M.A., 2003. Muddled or mixed? Inferring palaeoclimate from size

159 distributions of deep-sea clastics. Sedimentary Geology 162, 39-62.

160 Weltje, G.J., Prins, M.A., 2007. Genetically meaningful decomposition of grain-size

161 distributions. Sedimentary Geology 202, 409-424.

162

163 
Suppl. Table 1

Core Number Fig. 8 Depth Por B 14C date error

\section{ICELAND}

HM107-05

$1381 \mathrm{P} \quad 14100 \quad 140$

$2 \quad 394$ B $13690 \quad 100$

$3 \quad 394$ SHELL $\quad 13980 \quad 90$

B997-326PC

$18 \mathrm{~B}$

9040

110

$111 \mathrm{~B}$

9580

100

125 Vedde/Saks

$4 \quad 182$ P\&B $\quad 13835 \quad 215$

198 B $\quad 23570 \quad 340$

B997-323

48 Vedde?

$\begin{array}{llll}5 & 59 \mathrm{~B} & 13100 & 130\end{array}$

$\begin{array}{llll}61 & 13400 & 190\end{array}$

B997-338

$90 \mathrm{~B}$

$>25,00$

$21 \mathrm{~B}$

11560

170

tephra

$\begin{array}{llll}7 & 98.5 & 13020 & 220\end{array}$

8193 shell

13507

78

198 tephra

9

210 shell

13235

62

319.5 B

31900

1700

$412 \mathrm{~B}$

34600

640

MD99-2264

Vedde

$10 \quad 1169$ shell $\quad 11170 \quad 90$

$11 \quad 1339$ shell

12080

800

121705 shell

12714

86

13

2183 shell

13130

91

14

2749 shell

13469

89

37010 shell

53436

800

JM96-1234

349 B

14030

70

B997-336

501 shell

13680

70

HU90030-006LCF

15

$1175 \mathrm{~B}$

12690

195

16

$1235 B$

12810

205

$17 \mathrm{CC}$

13105

85

MD99-2256

18

1184 shell

11840

90

MD99-2259

19

2048 B

12790

120

E. GREENLAND

20

2261 shell

13790

80

HU93030-007PC

21

7.5 P--Nps

15270

120 


\begin{tabular}{|c|c|c|c|c|}
\hline MD99-2260 & 22 & $11 \mathrm{P}--\mathrm{Nps}$ & 16230 & 150 \\
\hline \multirow[t]{5}{*}{ JM96-1216/2 } & & $55 \mathrm{BF}$ & 8180 & 80 \\
\hline & & $95 \mathrm{BF}$ & 9580 & 100 \\
\hline & 23 & 210 shell & 10625 & 90 \\
\hline & 24 & 246 shell & 12040 & 80 \\
\hline & 25 & $B F$ & 14450 & 150 \\
\hline \multirow[t]{8}{*}{ BS1191-K18B } & & 4.5 & 1680 & 50 \\
\hline & & 37 & 5215 & 75 \\
\hline & & 62 & 9292 & 80 \\
\hline & & 77 & 9240 & 90 \\
\hline & 26 & $97 \mathrm{~B}$ & 12325 & 80 \\
\hline & $27>150$ & $\mathrm{Nps}$ & 12470 & 205 \\
\hline & 28 & $\mathrm{Nps}$ & 12085 & 115 \\
\hline & 29 & B & 12865 & 305 \\
\hline \multirow[t]{6}{*}{ P0175/1-5 } & & 29.5 P \& B & 13100 & 110 \\
\hline & 30 & $59.5 P \& B$ & 11995 & 145 \\
\hline & & $95 \mathrm{~B}$ & 13300 & 145 \\
\hline & 31 & 125 shell & 13024 & 120 \\
\hline & 32 & $194 \mathrm{~B}$ & 14465 & 200 \\
\hline & 33 & 311 B & 14845 & 190 \\
\hline \multirow[t]{6}{*}{ JM96-1213 } & & 100 & Vedde & \\
\hline & & 199 Triboculina & 14680 & 170 \\
\hline & 34 & 320.5 Bryozoa & 12630 & 80 \\
\hline & 35 & 389 B & 13690 & 230 \\
\hline & 36 & 439 N labradorica & 13356 & 108 \\
\hline & 37 & 473 Ex. Clavata & 13830 & 270 \\
\hline \multirow[t]{2}{*}{ MD99-2317 } & 38 & 1851 Ex. Clavata & 11567 & 88 \\
\hline & 39 & 1982 bryozoa & 11950 & 110 \\
\hline MD99-2322 & & 2436 shell & 10442 & 82 \\
\hline \multirow[t]{2}{*}{ JM96-1214 } & 40 & 562 B & 11380 & 80 \\
\hline & 41 & 469 Bryozoa & 12700 & 110 \\
\hline \multirow[t]{2}{*}{ JM96-1215 } & 42 & 495 P \& B & 12260 & 100 \\
\hline & $43>587$ & B & 12900 & 50 \\
\hline \multirow[t]{3}{*}{ JM96-1225 } & & $47.5 \mathrm{P}$ & 12455 & 65 \\
\hline & & 52.5180 transition & & \\
\hline & & $57 P$ & 15380 & 130 \\
\hline \multirow[t]{3}{*}{ JM96-1228 } & & $213 P$ & 15140 & 185 \\
\hline & & 220180 transition & & \\
\hline & & $231 \mathrm{P}$ & 16270 & 160 \\
\hline
\end{tabular}


$B=$ benthic forams

$\mathrm{P}=$ planktonic forams 


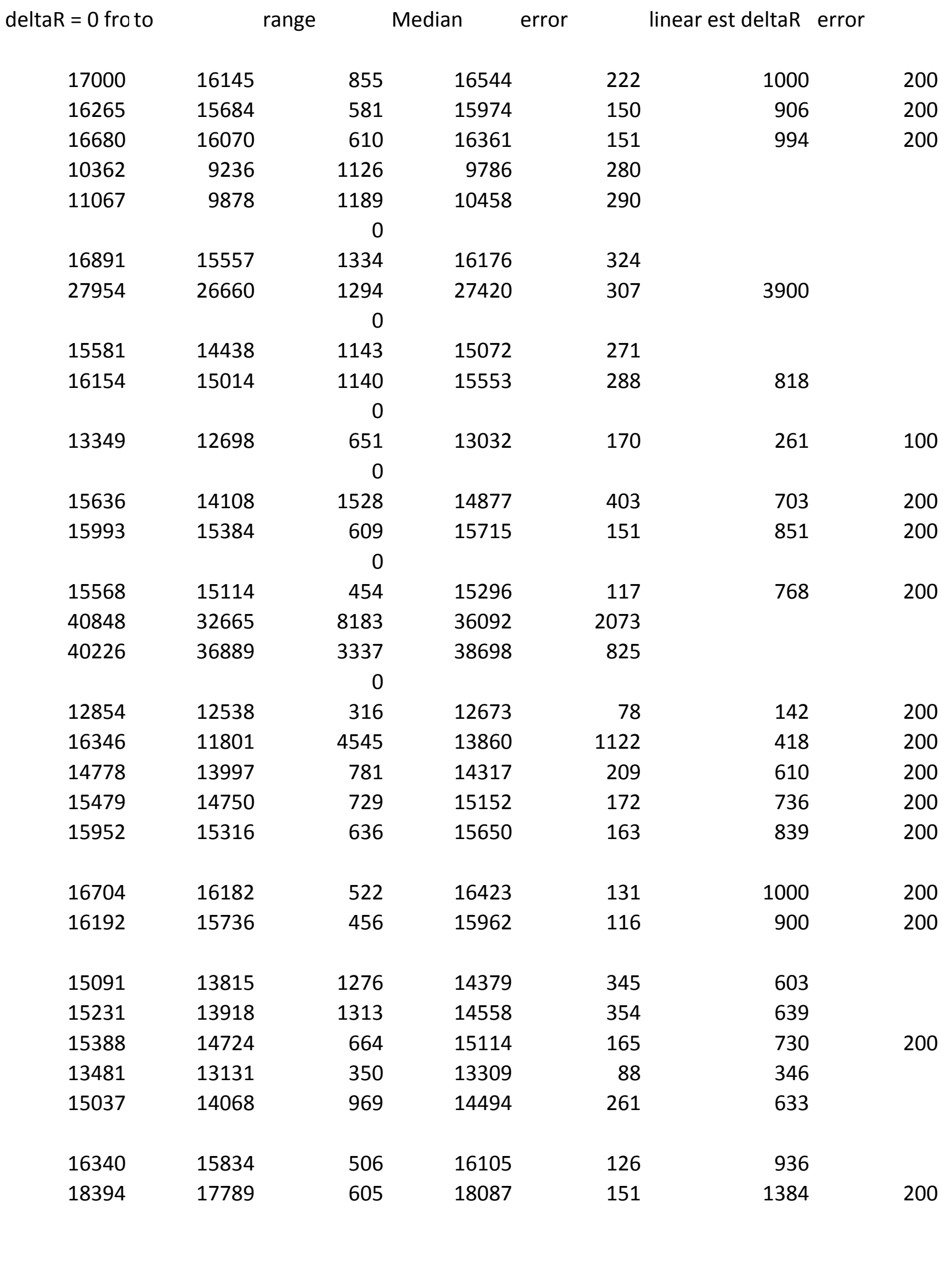




\begin{tabular}{|c|c|c|c|c|c|c|}
\hline 19496 & 18791 & 705 & 19106 & 183 & 1675 & 200 \\
\hline 8951 & 8481 & 470 & 8689 & 122 & & \\
\hline 10683 & 10215 & 468 & 10447 & 125 & & \\
\hline 12382 & 11464 & 918 & 11944 & 212 & -23 & \\
\hline \multirow[t]{2}{*}{13697} & 13316 & 381 & 13488 & 97 & 406 & 200 \\
\hline & & 0 & & & 1136 & 200 \\
\hline 1337 & 1128 & 209 & 1238 & 50 & & 100 \\
\hline 5755 & 5392 & 363 & 5576 & 86 & & 100 \\
\hline 10318 & 9850 & 468 & 10109 & 114 & & 100 \\
\hline 10239 & 9732 & 507 & 100031 & 131 & & 100 \\
\hline 14010 & 13568 & 442 & 13795 & 108 & 492 & 200 \\
\hline 14792 & 13464 & 1328 & 14003 & 335 & 536 & 200 \\
\hline 13806 & 13311 & 495 & 13545 & 127 & 420 & 200 \\
\hline \multirow[t]{2}{*}{15163} & 14094 & 1069 & 14623 & 296 & 656 & 200 \\
\hline & & 0 & & & & \\
\hline 15537 & 14563 & 974 & 15089 & 226 & 727 & 200 \\
\hline 13785 & 13185 & 600 & 13460 & 152 & 392 & \\
\hline 15906 & 14975 & 931 & 15420 & 231 & 788 & 200 \\
\hline 15709 & 14826 & 883 & 15267 & 215 & 704 & 200 \\
\hline 17633 & 16458 & 1175 & 17078 & 299 & 1141 & 200 \\
\hline \multirow[t]{3}{*}{18043} & 17074 & 969 & 17589 & 247 & 1256 & 200 \\
\hline & & 0 & & & & \\
\hline & & 0 & & & 1206 & 200 \\
\hline 14554 & 13885 & 669 & 14139 & 163 & 585 & 200 \\
\hline 16642 & 15268 & 1374 & 15965 & 344 & 906 & 200 \\
\hline 15829 & 15163 & 666 & 15489 & 173 & 805 & 200 \\
\hline 16985 & 15355 & 1630 & 16175 & 406 & 948 & 200 \\
\hline 13250 & 12815 & 435 & 13042 & 109 & 263 & 200 \\
\hline 13667 & 13196 & 471 & 13407 & 115 & 379 & 200 \\
\hline 11915 & 11250 & 665 & 11571 & 179 & -78 & 200 \\
\hline 13055 & 12671 & 384 & 12845 & 98 & 206 & 200 \\
\hline 14862 & 13938 & 924 & 14320 & 242 & 606 & 200 \\
\hline 13961 & 13470 & 491 & 13718 & 125 & 473 & 200 \\
\hline 15052 & 14313 & 739 & 14720 & 196 & 667 & 200 \\
\hline \multirow[t]{2}{*}{14107} & 13770 & 337 & 13937 & 86 & 532 & 200 \\
\hline & & 0 & 16180 & & & \\
\hline 18529 & 17900 & 629 & 18205 & 160 & 1420 & 200 \\
\hline \multirow[t]{2}{*}{18387} & 17494 & 893 & 17936 & 227 & 871 & 200 \\
\hline & & 0 & & & & \\
\hline 19547 & 18810 & 737 & 19153 & 194 & 1690 & 200 \\
\hline
\end{tabular}



version for accuracy and citation."

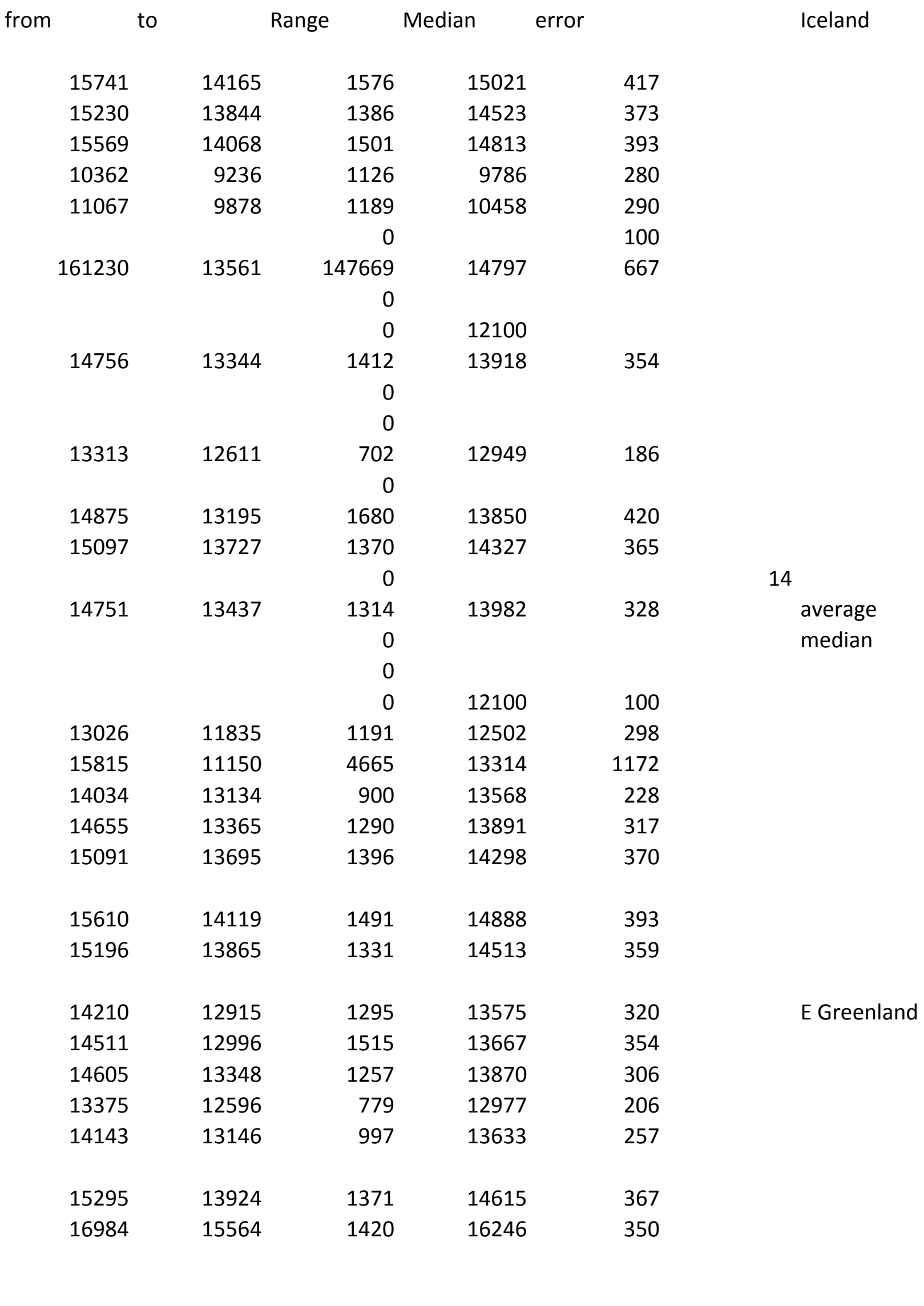

http://mc.manuscriptcentral.com/jqs 


\begin{tabular}{|c|c|c|c|c|c|}
\hline \multirow[t]{4}{*}{17862} & 16460 & 1402 & 17190 & 354 & \\
\hline & & 0 & & & \\
\hline & & 0 & & & \\
\hline & & 0 & & & \\
\hline 13485 & 12675 & 810 & 13098 & 209 & \\
\hline 16156 & 14405 & 1751 & 15405 & 428 & \\
\hline 1471 & 981 & 490 & 1229 & 119 & \\
\hline 5859 & 5305 & 554 & 5576 & 143 & \\
\hline 10434 & 9687 & 747 & 10087 & 184 & \\
\hline 10366 & 9608 & 758 & 10013 & 188 & \\
\hline 13749 & 12830 & 919 & 13297 & 226 & \\
\hline 14012 & 12794 & 1218 & 13413 & 309 & \\
\hline 13559 & 12670 & 889 & 13129 & 226 & \\
\hline \multirow[t]{2}{*}{14956} & 12946 & 2010 & 13795 & 495 & \\
\hline & & 0 & & & \\
\hline \multirow[t]{2}{*}{14637} & 13343 & 1294 & 13871 & 317 & average \\
\hline & & 0 & & & \\
\hline 14991 & 13466 & 1525 & 14095 & 397 & median \\
\hline 14647 & 13269 & 1378 & 13818 & 336 & \\
\hline 16221 & 14303 & 1918 & 15410 & 478 & \\
\hline \multirow[t]{2}{*}{16685} & 14971 & 1714 & 15810 & 421 & \\
\hline & & 0 & 12100 & 100 & \\
\hline 16447 & 14742 & 1705 & 15642 & 411 & \\
\hline 13986 & 13090 & 896 & 13519 & 224 & \\
\hline 15531 & 13675 & 1856 & 14550 & 474 & \\
\hline 14993 & 13535 & 1458 & 14144 & 377 & \\
\hline 15755 & 13736 & 2019 & 14688 & 523 & \\
\hline 13164 & 12094 & 1070 & 12701 & 263 & \\
\hline \multirow[t]{2}{*}{13453} & 12629 & 824 & 13043 & 216 & \\
\hline & & 0 & & & \\
\hline 13130 & 12060 & 1070 & 12667 & 267 & \\
\hline 14065 & 13112 & 953 & 13570 & 241 & \\
\hline 13708 & 12772 & 936 & 13250 & 231 & \\
\hline 14150 & 13271 & 879 & 13701 & 231 & \\
\hline \multirow[t]{2}{*}{13836} & 12936 & 900 & 13391 & 221 & \\
\hline & & 0 & & & \\
\hline 17080 & 15670 & 1410 & 16356 & 355 & \\
\hline \multirow[t]{2}{*}{17556} & 16040 & 1516 & 16794 & 390 & \\
\hline & & 0 & & & \\
\hline 17897 & 16478 & 1419 & 17223 & 360 & \\
\hline
\end{tabular}


from

to

median cal

$\begin{array}{lll}14605 & 13348 & 13870 \\ 15741 & 14165 & 15021 \\ 15230 & 13844 & 14523 \\ 16230 & 13561 & 14797 \\ 14756 & 13344 & 13918 \\ 13313 & 12611 & 12949 \\ 14875 & 13195 & 13850 \\ 15097 & 13727 & 14327 \\ 13026 & 11835 & 12502 \\ 15815 & 11150 & 13314 \\ 14034 & 13134 & 13568 \\ 14655 & 13365 & 13891 \\ 14210 & 12915 & 13575 \\ 14511 & 12996 & 13667 \\ 13375 & 12596 & 12977 \\ 14143 & 13146 & 13633 \\ 15295 & 13924 & 14615 \\ 14644 & 13094 & 13820 \\ 14706 & 13171 & 13759\end{array}$

16544

15974

16361

15072

15553

14877

15715

15296

14317

15152

15650

14379

15114

13309

14494

16105

29

30

31

32

33

34

35

36

37

38

39

40

41

42

43

44

45

46

47

48

49

50

51

52

53

54

55

56

\begin{tabular}{|c|c|c|c|}
\hline \multicolumn{3}{|c|}{ median cal } & \\
\hline 13485 & 12675 & 13098 & \\
\hline 16156 & 14405 & 15405 & \\
\hline 13749 & 12830 & 13297 & \\
\hline 14012 & 12794 & 13413 & 14623 \\
\hline 14637 & 13343 & 13871 & 15420 \\
\hline
\end{tabular}

http://mc.manuscriptcentral.com/jqs 


$\begin{array}{lrrr}14991 & 13466 & 14095 & 15267 \\ 14647 & 13269 & 13818 & 17078 \\ 16221 & 14303 & 15410 & 17589 \\ 16685 & 14971 & 15810 & 14139 \\ 13986 & 13090 & 13519 & 15965 \\ 15531 & 13675 & 14550 & 15489 \\ 14993 & 13535 & 14144 & 16175 \\ 15755 & 13736 & 14688 & 14320 \\ 13164 & 12094 & 12701 & 13718 \\ 13453 & 12629 & 13043 & 14720 \\ 13130 & 12060 & 12667 & 13937 \\ 14065 & 13112 & 13570 & 15264.6154 \\ 13708 & 12772 & 13250 & 13.9-14.2 \\ 14150 & 13271 & 13701 & \\ 14554 & 13265 & 13897 & \\ 14150 & 13269 & 13701 & \end{array}$


Suppl. Table 2

$\begin{array}{ll}\begin{array}{l}\text { Lipari obsidian standard } \\ \text { CU Lab } \mathrm{n}=10\end{array} & \begin{array}{l}\text { Mean } \\ \text { sd }\end{array} \\ \text { B99-338 } & \\ 90 \mathrm{~cm} & \text { Mean } \\ \mathrm{n}=3 & \text { SD } \\ 99-101 \mathrm{~cm} & \text { Mean } \\ \mathrm{n}=9 & \text { SD } \\ 190 \mathrm{~cm} & \text { Mean } \\ \mathrm{n}=9 & \text { SD } \\ 192-194 \mathrm{~cm} & \text { Mean } \\ \mathrm{n}=9 & \text { SD }\end{array}$

SiO2 TiO2 203 FeO* MnO

Borrobol type $\mathrm{n}=10$

Lind et al 2016--Table 2 Mean standard deviation

74.12

$0.07 \quad 12.98$

1.67

0.07

0.86

$0.03 \quad 0.41$

0.21

0.02

$\begin{array}{rrrrr}78.8 & 0.2 & 13.1 & 3.3 & 0.1 \\ 0.5 & 0.0 & 0.3 & 0.1 & 0.0 \\ 74.0 & 0.3 & 14.0 & 3.8 & 0.1 \\ 4.8 & 0.1 & 1.9 & 0.7 & 0.0 \\ 74.0 & 0.3 & 14.0 & 3.8 & 0.1 \\ 4.8 & 0.1 & 1.9 & 0.7 & 0.0 \\ 77.1 & 0.3 & 11.7 & 5.7 & 0.1 \\ 1.5 & 0.2 & 1.4 & 2.4 & 0.1\end{array}$

76.67

$0.13 \quad 12.71$

1.56

0.04

0.35

0.01

0.25

0.17

0.01

Similaritycoefficent

Borrobol v $90 \mathrm{~cm}$

0.997

Borrobol v $100 \mathrm{~cm}$

0.742

Borrobol v $90 \mathrm{~cm}$

0.742

Borrobol v $193 \mathrm{~cm}$

0.830

B997-326

B997-323

Basalt tephras

$156 \mathrm{~cm}$

$69 \mathrm{~cm}$ mean

$\mathrm{sd}$

$94 \mathrm{~cm}$ mean

sd

$\begin{array}{rrrrr}49.18 & 0.53 & 14.18 & 8.42 & 0.17 \\ 50.04 & 2.20 & 13.16 & 12.96 & 0.23 \\ 0.64 & 0.47 & 0.56 & 0.89 & 0.02 \\ 50.68 & 3.35 & 13.28 & 13.69 & 0.24 \\ 1.56 & 1.01 & 1.26 & 1.33 & 0.03\end{array}$


MgO CaO Na2O k20 P2O3 Total

$\begin{array}{llllll}0.04 & 0.77 & 3.74 & 5.03 & 0.01 & 98.48 \\ 0.01 & 0.11 & 0.16 & 0.25 & 0.02 & \end{array}$

$\begin{array}{llllll}0.0 & 0.5 & 1.4 & 3.0 & 0.0 & 100.2\end{array}$

$\begin{array}{lllll}0.0 & 0.0 & 0.5 & 0.3 & 0.0\end{array}$

$\begin{array}{llllll}0.1 & 1.1 & 2.4 & 3.4 & 0.0 & 99.2\end{array}$

$\begin{array}{lllll}0.2 & 0.9 & 1.4 & 0.8 & 0.0\end{array}$

$\begin{array}{llllll}0.1 & 1.1 & 2.4 & 3.4 & 0.0 & 99.2\end{array}$

$\begin{array}{lllll}0.2 & 0.9 & 1.4 & 0.8 & 0.0\end{array}$

$\begin{array}{llllll}0.0 & 0.4 & 1.4 & 3.1 & 0.0 & 99.8\end{array}$

$\begin{array}{lllll}0.0 & 0.0 & 0.5 & 0.6 & 0.0\end{array}$

$\begin{array}{lllll}0.08 & 0.75 & 4.03 & 4.01 & 0.01\end{array}$

$\begin{array}{lllll}0.02 & 0.06 & 0.47 & 0.12 & 0.01\end{array}$

$\begin{array}{rrrrrr}10.28 & 15.76 & 1.39 & 0.04 & 0.05 & 100.00 \\ 6.95 & 10.96 & 2.47 & 0.21 & 0.28 & 99.47 \\ 0.60 & 0.44 & 0.21 & 0.06 & 0.29 & 0.83 \\ 5.38 & 9.40 & 2.86 & 0.57 & 0.38 & 99.83 \\ 1.54 & 1.54 & 0.56 & 0.41 & 0.16 & 1.25\end{array}$




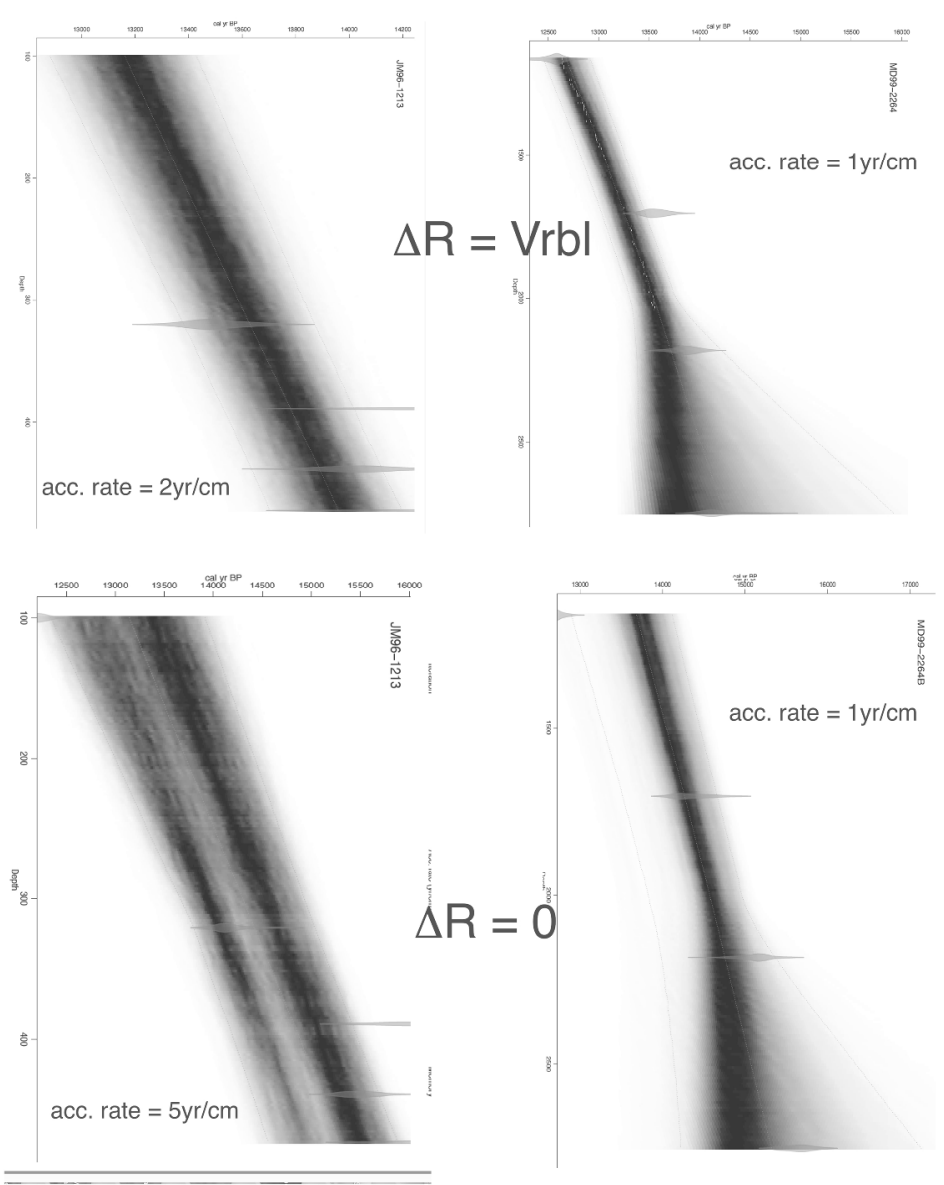




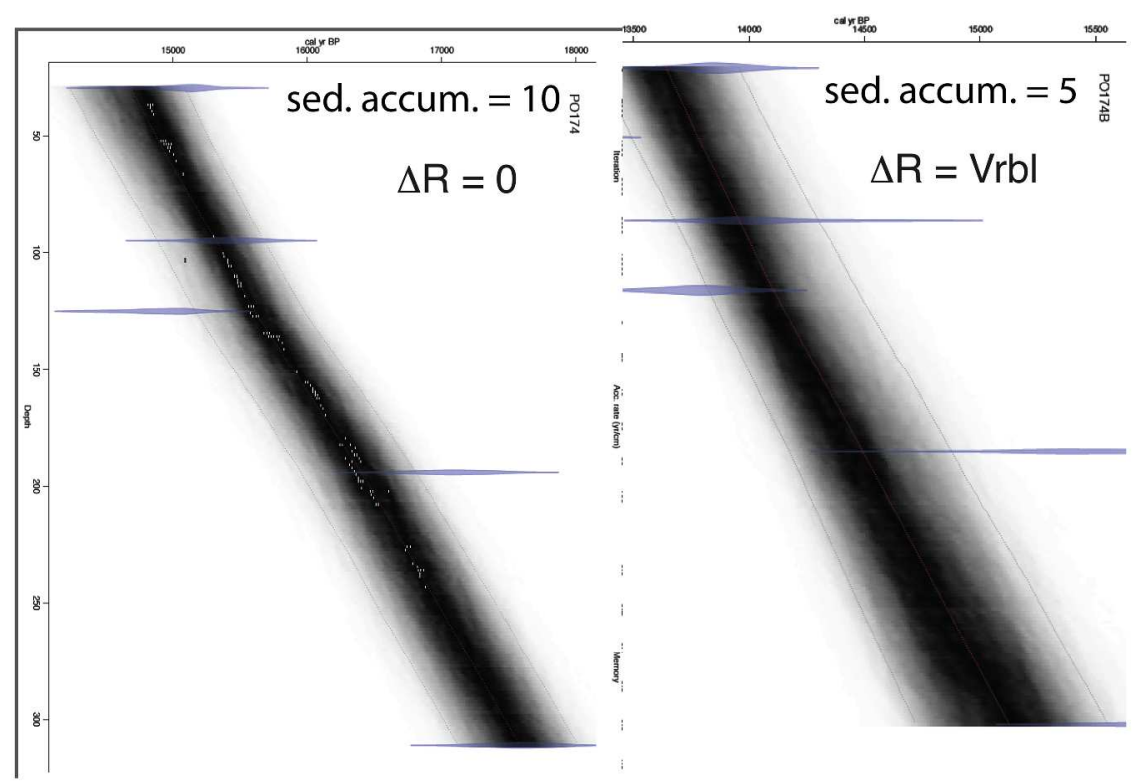

